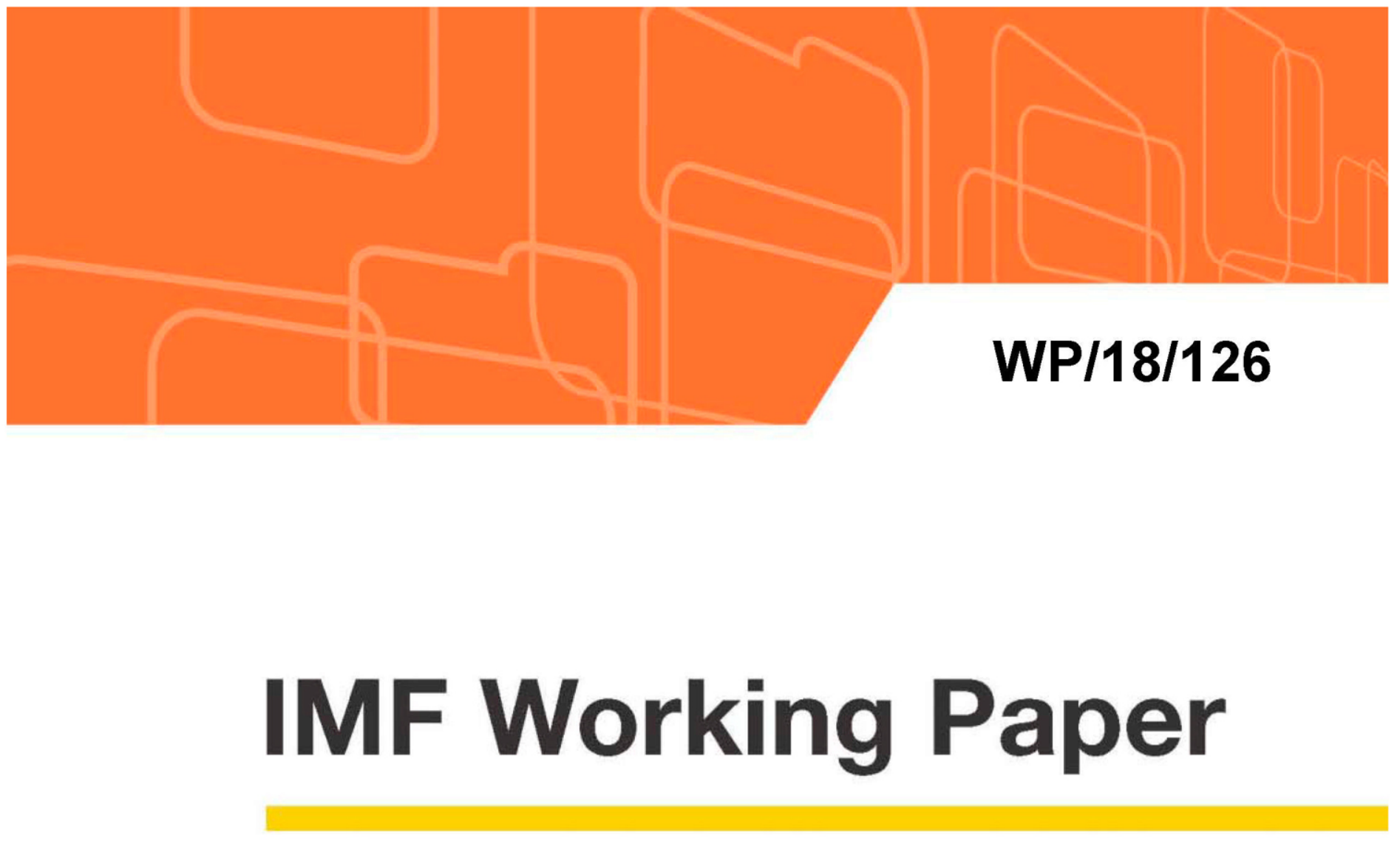

\title{
Labor Market Duality in Korea
}

by Johanna Schauer

IMF Working Papers describe research in progress by the author(s) and are published to elicit comments and to encourage debate. The views expressed in IMF Working Papers are those of the author(s) and do not necessarily represent the views of the IMF, its Executive Board, or IMF management. 


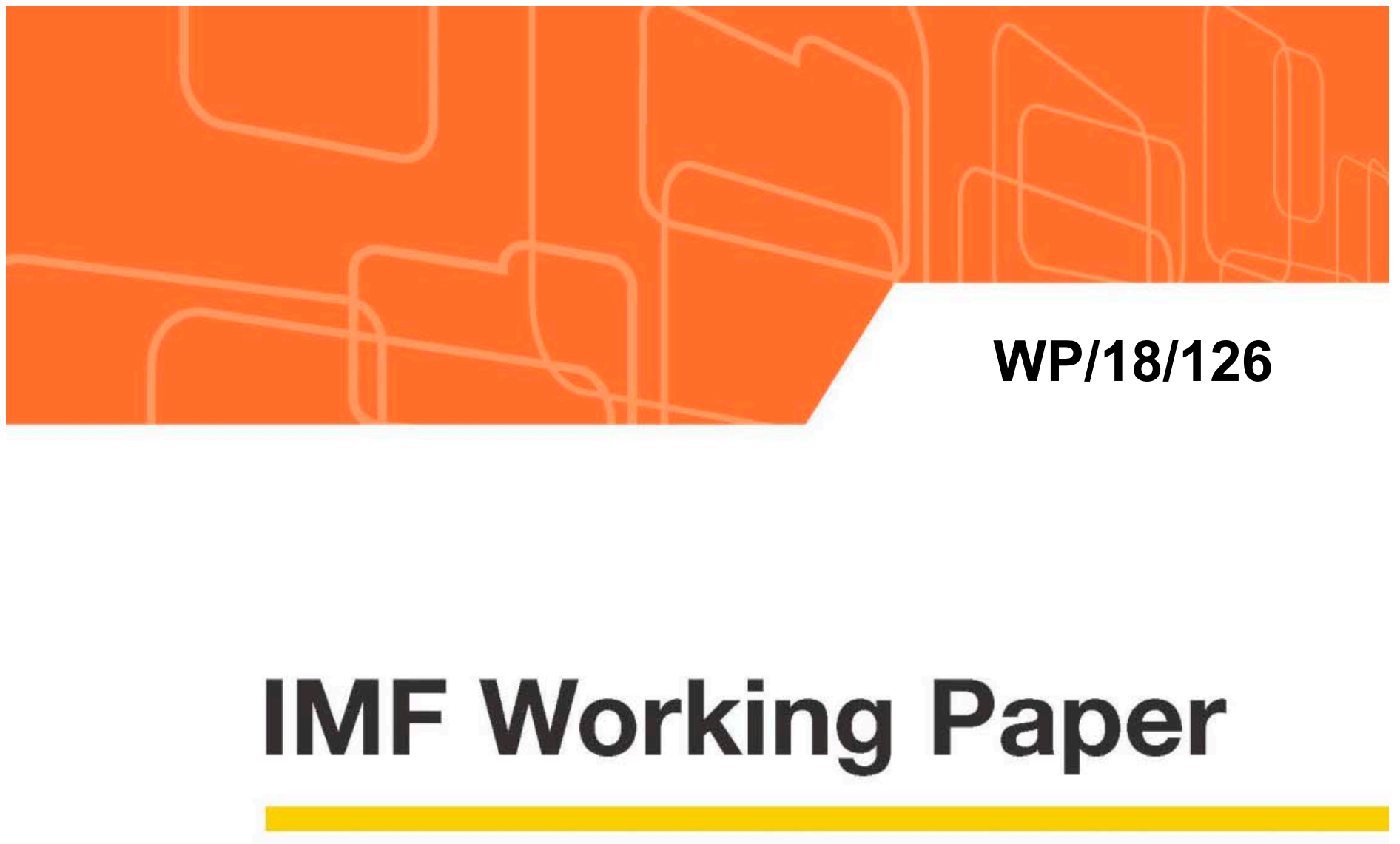

\title{
Labor Market Duality in Korea
}

\author{
by Johanna Schauer
}

IMF Working Papers describe research in progress by the author(s) and are published to elicit comments and to encourage debate. The views expressed in IMF Working Papers are those of the author(s) and do not necessarily represent the views of the IMF, its Executive Board, or IMF management.

I N T E R N A T I O N A L M O N E T A R Y F U N D 


\title{
IMF Working Paper
}

Asia and Pacific Department

\section{Labor Market Duality in Korea1}

Prepared by Johanna Schauer

Authorized for distribution by Tarhan Feyzioğlu

June 2018

\section{IMF Working Papers describe research in progress by the author(s) and are published to elicit comments and to encourage debate. The views expressed in IMF Working Papers are those of the author(s) and do not necessarily represent the views of the IMF, its Executive Board, or IMF management.}

\begin{abstract}
Labor market duality is a complex and critical issue for many countries that can lower productivity, contribute to inequality and result in negative externalities. In this paper, I study duality in the Korean labor market and analyze its sources and potential policy options. I find that employment protection legislations and large productivity differentials are the key drivers of Korea's duality. In addition, applying a general equilibrium search-and-matching model and calibrating it to the Korean economy, I show that well-calibrated flexicurity policies can significantly reduce duality and inequality and raise welfare and productivity. Notably, the introduction of all three pillars - flexiblity, a strong safety net and active labor market policies - is critical for its success. If only one pillar is introduced it can result in negative side-effects and might not reduce duality.
\end{abstract}

JEL Classification Numbers: E24, J08, J21

Keywords: Korea, Labor market duality, flexicurity

Author's E-Mail Address: JSchauer@imf.org

\footnotetext{
${ }^{1}$ This paper has greatly benefitted from comments by and discussions with Tarhan Feyzioğlu, staff at MoSF, MoEL, KDI and KLI, Etienne Lalé, Evan Papageorgiou, Jaebin Ahn, Callum Jones, Rodrigo Montes and NielsJakob Hansen. All errors are my own.
} 


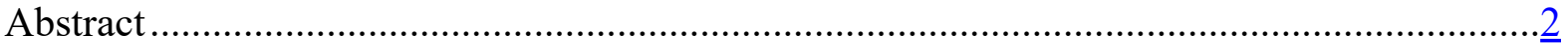

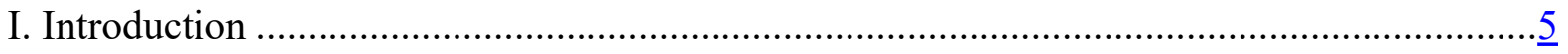

II. How Has Duality Evolved in Korea? What is Its Current State?..........................................

III. What is the Impact of Labor Market Duality in Korea? ..................................................... $\underline{8}$

IV. What Explains Labor Market Duality in Korea? ………..............................................

V. How Can Policy Address Labor Market Duality? ...............................................................

A. What is Flexicurity and When Does it Work? ....................................................19

B. A Model of Labor Market Duality …………………………………………........

C. Calibration to the Korean Economy ………………………………………….......24

D. Putting Flexicurity to the Test..............................................................................26

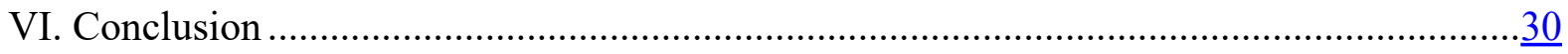

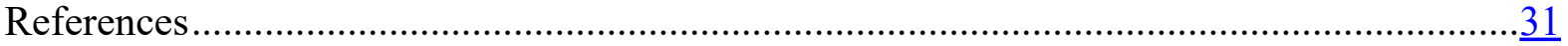

Tables

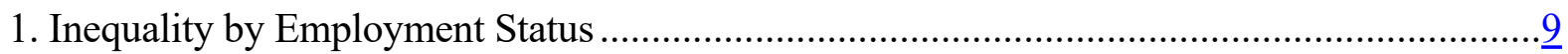

2. Flow Probability by Employment Status (2013-14) ……………….............................

3. Regression on Number of On-the-Job Trainings ………..............................................11

4. Wages and Working Conditions by Firm Size and Employment Type...............................14

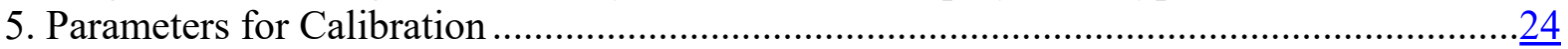

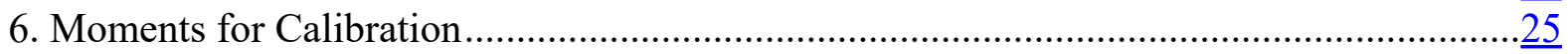

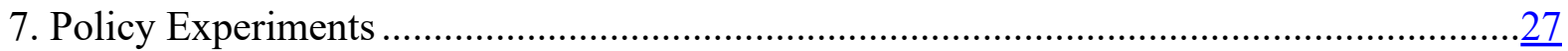

Figures

1. Non-Regular Employment ...................................................................................

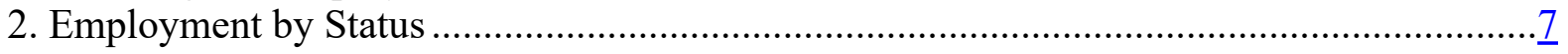

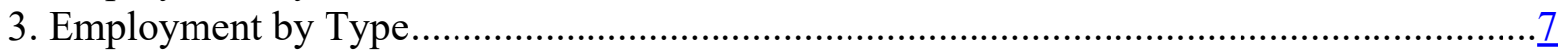

4. Employment by Gender ...........................................................................................

5. Employment by Age and Highest Education Level.........................................................

6. Employment by Sector...........................................................................................

7. Employmen by Firm Size ………………………….............................................

8. Relative Wage of Non-Regular Employment Types ..........................................................

9. Social Coverage by Employment Type ……………...............................................

10. Income Distribution by Employment Status ..............................................................

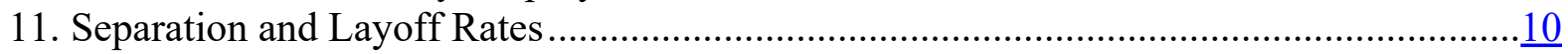

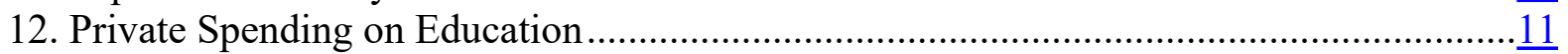

13. Dismissal Regulation for Regular Workers …………............................................

14. Severance Pay for Redundancy Dismissal.................................................................. 
15. Relative Labor Productivity .........................................................................................14

16. Relative Wages in Services by Employment Type.....................................................

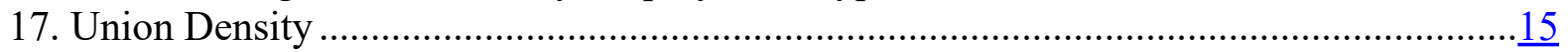

18. Trade Union Density by Employment Type ...........................................................

19. Changes in Employment Shares by Wage Level ..........................................................

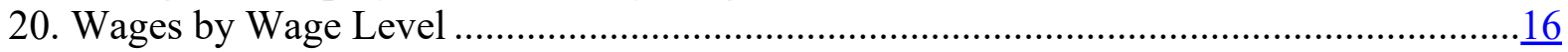

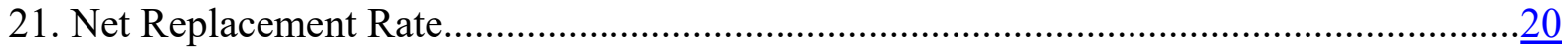

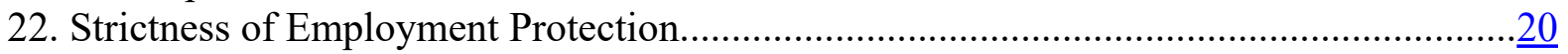

23. Spending on Active Labor Market Policies ...............................................................

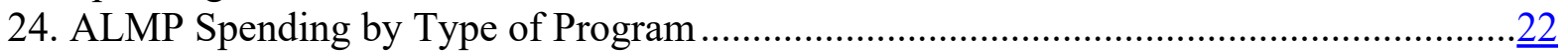

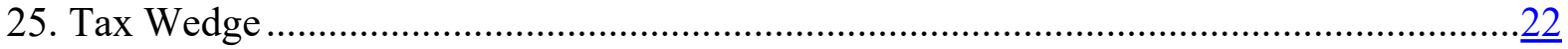

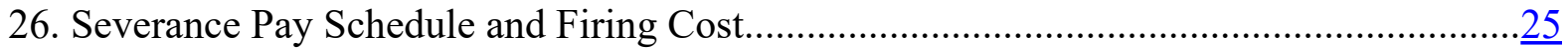

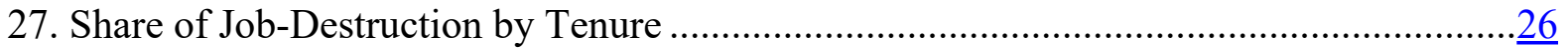

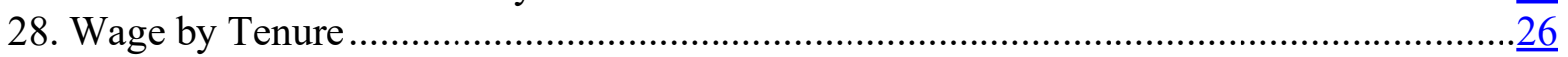

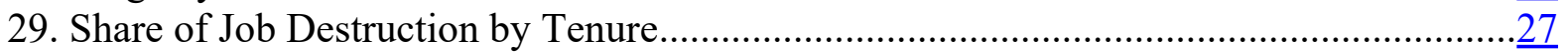

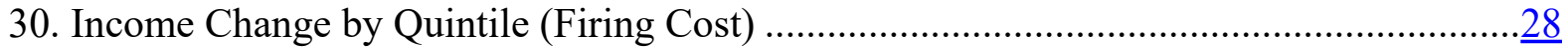

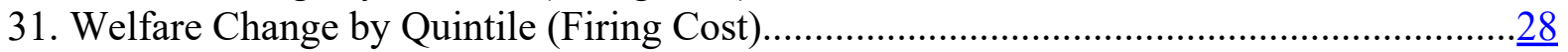

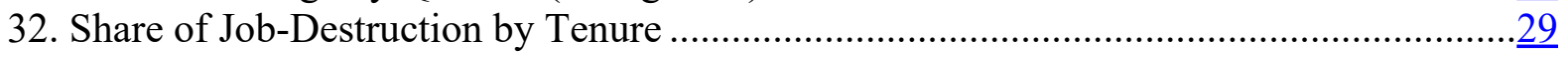

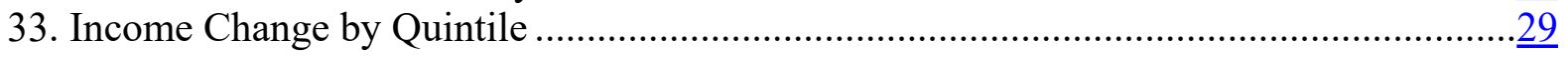

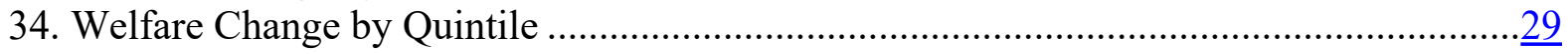

Boxes

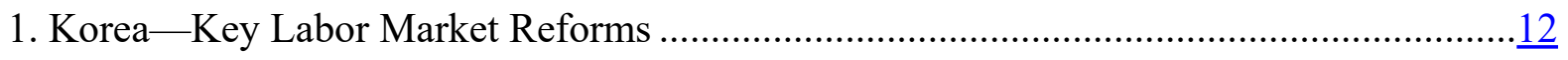

2. Women, Elderly and Youth-Why Does Non-Regular Work Affect Them

Disproportionately? 


\section{INTRODUCTION}

Duality is usually employed to characterize a labor market consisting of two tiers. In the regular tier workers enjoy high wages and social benefits - such as unemployment insurance and pensions - and have a high degree of job security. In the non-regular tier workers tend to receive lower wages, are less likely to be covered by social benefits and have lower levels of job security. In practice, non-regular work can take many forms, with potential for overlap. Often it is defined using types of employment contracts. The OECD provides cross-country data for three forms of employment that could be classified as non-regular: temporary, part-time and selfemployment. ${ }^{2}$ Compared to other OECD countries Korea stands out for having a relatively high share of temporary and self-employed workers (see Figure 1). With regards to part-time employment, Korea lies below the OECD average. However, beyond the incidence of non-regular employment contracts, it is critical to examine the impact of duality on individuals' lifes and the economy

Figure 1: Non-Regular Employment (Share in total employment)
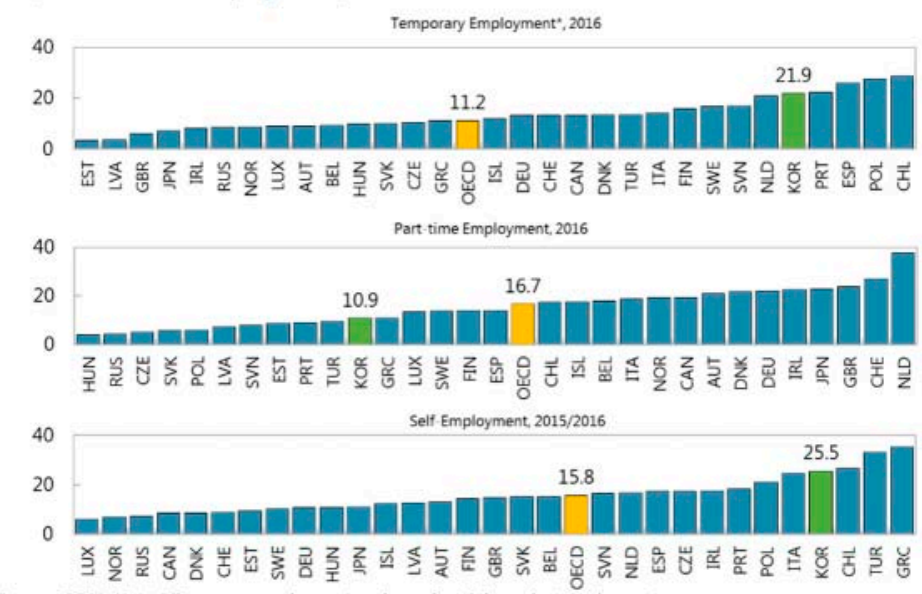
Sources: OECD. Note: " Temporary employment as share of total dependent employment and society as a whole.

\section{The existence of different employment arrangements is not an inherent concern in} itself. On the contrary, they can serve different priorities of employers and workers and thereby enhance welfare. For example, part-time contracts might be preferred by individuals desiring higher work flexibility and can raise labor force participation. Temporary contracts can be used as a screening device by employers, which can lower skill mismatches. In general, a certain variety in employment arrangements has the potential to lower unemployment and in particular long-term unemployment and reduce loss of skills.

\section{Labor market duality can become a significant problem if it results in inefficiencies and welfare losses. These can work through various channels:}

- $\quad$ Labor market duality can reduce productivity. In particular, if non-regular employment arrangements result in recurring spells of short-term employment and unemployment, this can cause an inefficent 'revolving door'. It can lower investment

\footnotetext{
2 Temporary employment is any wage or salary employment, which has a pre-determined termination date. While most data of countries broadly conform with this definition, there are some that slightly differ. For example, Japan only considers temporary contracts to be those that last one year or less. For Korea, temporary workers include workers with a work contract of limited durations, temporary agency workers and on-call workers (see OECD, 2017a). Workers in part-time employment are those who usually work less than 30 hours per week. Self-employment groups workers, who work for themselves, for co-operatives or are unpaid family workers. Note that there is room for overlap as temporary workers or self-employed might also be part-time employed.
} 
in on-the-job training (Cabrales et al., 2014) and reduce exerted effort (Bentolila and Dolado, 1994; Dolado et al et., 2016). It could also incentivize firms to create more low productivity jobs (Blanchard and Landier, 2001) and to invest into mature rather than innovative technologies (Saint-Paul, 2002). Moreover, it can cause skill mismatches among regular and non-regular workers (McGowan and Andrews, 2015).

- $\quad$ Labor market duality can contribute to inequality. Duality can induce insideroutsider dynamics, with regular workers enjoying higher bargaining power and ensuring higher wages and job-security (Bentolila and Dolado, 1994; Lindbeck and Snower, 2002). This can result in very different working conditions for similar work, which can reduce social cohesion and erode support for important economic measures (Aoyagi and Ganelli, 2013). Second round effects of differences in income and working conditions can lead to protracted inequality and loss of intergenerational mobility, e.g. by reducing non-regular workers' investment into their childrens' education (OECD, 2016).

- $\quad$ Labor market duality can result in negative externalities. Firms might not internalize social costs of non-regular employment arrangements. For example, if workers are risk-averse lower unemployment insurance or job-security associated with nonregular employment can reduce welfare (Dolado et al., 2017). Furthermore, high jobturnovers with intermittent unemployment spells can strain public expenditure on unemployment insurance and result in disequlibrium in public finances (Bentolila and Dolado, 1994).

\title{
II. How Has Duality Evolved in Korea? What is Its CurRent State?
}

\begin{abstract}
Korea's labor market duality is complex, and there are different definitions to capture different types of employment. In 2002, the Economic and Social Development Commission achieved an agreement on the scope and statistics of non-regular workers. Under the agreement, non-regular workers include temporary or fixed-term workers, partterm workers and temporary agency workers. ${ }^{3}$ These criteria reflect the unique characteristics of the Korean labor market and differ somewhat from those used in the OECD or other international institutions, e.g. with regards to classifying temporary workers. However, depending on the data source and focus of the data analysis, the definition of regular and non-regular workers can still vary significantly (Grubb et al., 2007; Ha and Lee, 2013). Two main classifications from the national statistics office can be distinguished (see Appendix A1). The first classification separates the working population by status. This allows to identify self-employed and temporary workers with contracts of less than a year. A further classification is available by employment type. It provides information on part-time workers, non-typical workers and non-permanent workers. It is important to note that the latter classification is non-exclusive, e.g. a worker can be classified as part-time and nonpermanent at the same time.
\end{abstract}

\footnotetext{
${ }^{3}$ It is important to note that under this definition the self-employed are not included in non-regular employment. As a significant share of the self-employed appears to share characteristics with the second-tier labor market and to ensure a comprehensive analysis, this paper will include them in the following analysis.
} 
Different types of non-regular employment have experienced varying trends over time. A classification of employment by status suggests that the share of non-salaried workers declined significantly from 41 percent in 1989 to 25 percent in 2016 (see Figure 2). The share of temporary workers remained largely unchanged. Standing at 27 percent in 1989 it peaked at 33 percent in 2002 and subsequently declined to 25 percent in 2016 . A break-down by employment type suggests that the incidence of non-regular workers has remained relatively constant since 2003 (see Figure 3). However, the share of part-time employment has increased from 7 percent in 2003 to 11 percent in 2014. In addition, it has also been found that subcontract work has increased since the Asian financial crisis (Cooke and Brown, 2015).

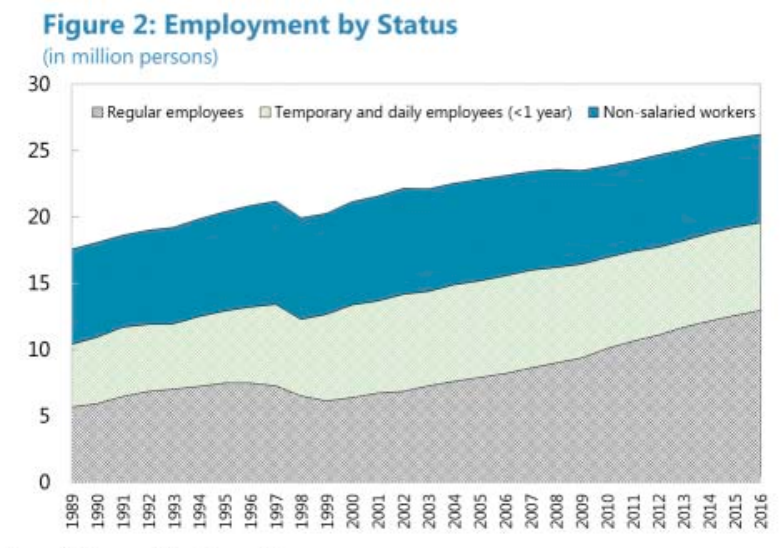

Kosis, economically active population survey.

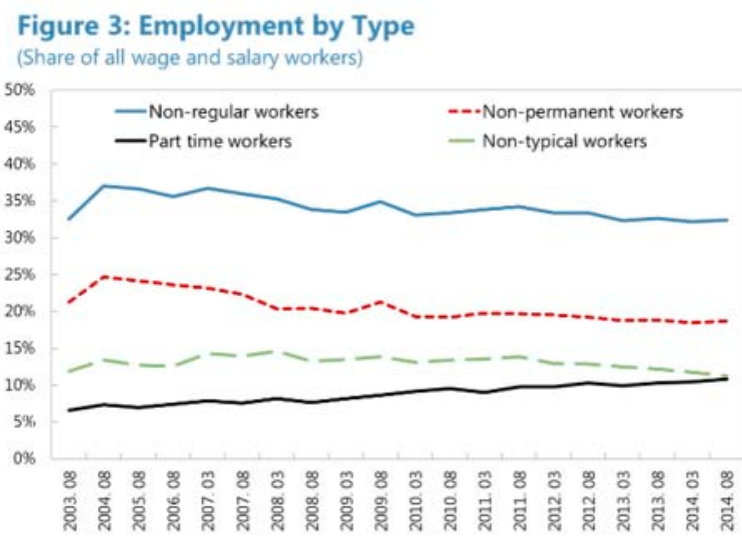

Source: Kosis, economically active population survey, additional survey by employment type.

The total share of non-regular employment ranges from 23 to 50 percent, depending on its definition. While the two classifications provide a picture of different types of nonregular work, they do not allow conclusions of the overall share of non-regular workers. For this type of analysis, a matrix approach has been suggested which considers both employment type and status. Using this approach, Kim (2011) finds that in 201123.4 percent of paid workers were non-regular in both classification (i.e., they had a contract that was temporary and contingent, part-time, or atypical). If classifiying all of those as non-regular, who were non-regular in at least one of the dimensions, the share has been estimated at about 49 percent of total employment (Ha and Lee, 2013).

Women, youth and the elderly account for disproportionately large shares of nonregular employment. While less than 40 percent of regular workers were women, they held 55 percent of temporary and more than 70 percent of part-time contracts (see Figure 4). Youth and the elderly only held about 23 percent of regular jobs, but 43 percent of nonpermanent and 56 percent of part-time employment (see Figure 5). In addition, micro data from the Korean Labor and Income Panel Study (KLIPS) suggests that the level of education also differs by employment status of workers (see Figure 5). While about 34 percent of regular workers had only a high school education or less, this share was twice as high for temporary and daily (67 percent) and non-salaried workers (66 percent). ${ }^{4}$

\footnotetext{
${ }^{4}$ For a discussion of the KLIPS data see Appendix A2.
} 

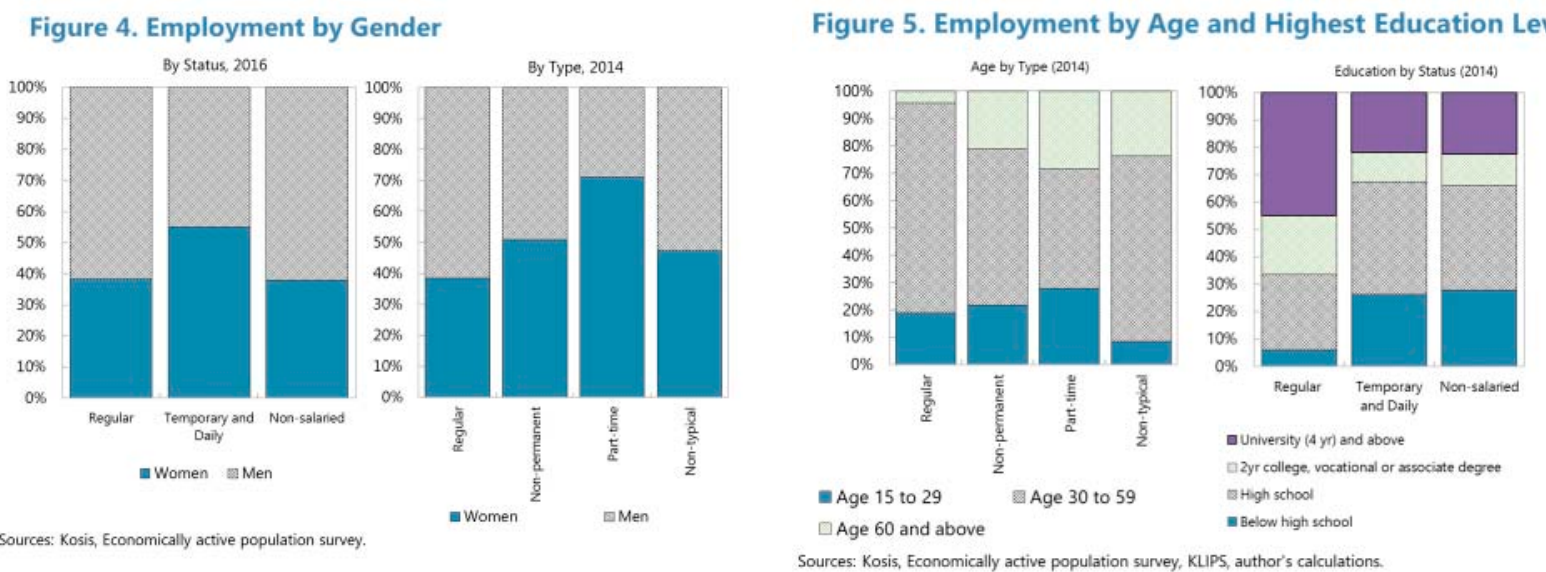

Most non-regular workers are employed in small firms and the service sector. In general, most Koreans are employed in the service sector. Among permanent workers about 68.5 percent are employed in the service sector, while for temporary and daily employees the share stood at 73.9 percent (see Figure 6). It was highest for part-time workers at 90 percent. Construction also accounts for a relatively large share of non-regular workers when compared to regular workers. A similar conclusion holds for small firms (see Figure 7). They provide about half of all regular jobs. However, they account for 65 percent of temporary and daily employment and 77 percent of non-salaried workers.
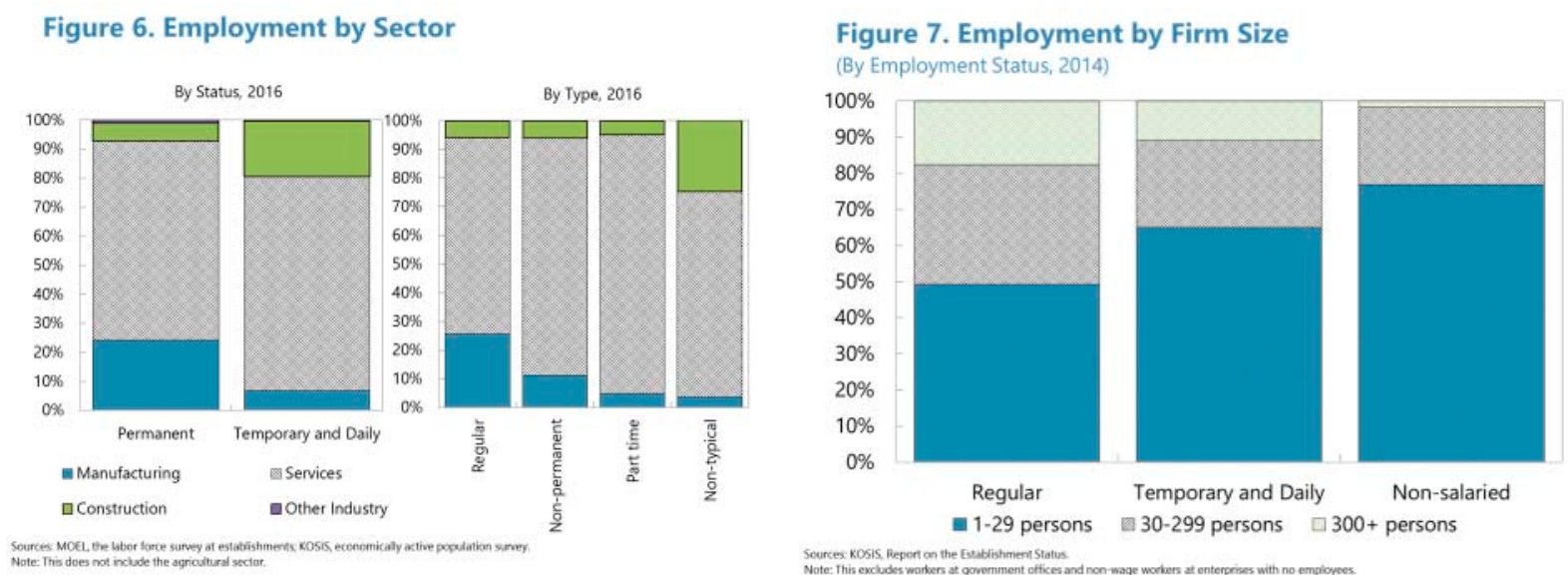

\section{What IS THE IMPACT OF LABOR MARKET DUALITY IN KOREA?}

Non-regular workers in Korea tend to receive lower wages and are less likely to enjoy social benefits. Fixed-term workers receive on average about 66 percent of the hourly wage of regular workers, while part-time workers earn on average 62 percent and agency workers about 52 percent (see Figure 8). However, some of these gaps could be explained by differences in e.g., education, firm size, ability or tenure. Existing studies trying to control for these factors found varying significance and sizes of the wage gap (Ha and Lee, 2013). Regarding the potential explanation of preferences, surveys suggest that more than half of non-regular workers would prefer regular employment (Cooke and Brown, 2015). With respect to social benefits, almost all regular workers are covered by employment insurance, health insurance and the national pension (see Figure 9). This is also true for most fixed-term and agency workers. Much less of part-time workers receive these social benefits, even 
though the share has more than doubled since 2007. The data does not include self-employed workers, who are likely to have even lower coverage as e.g., participation in the employment insurance scheme is voluntary.

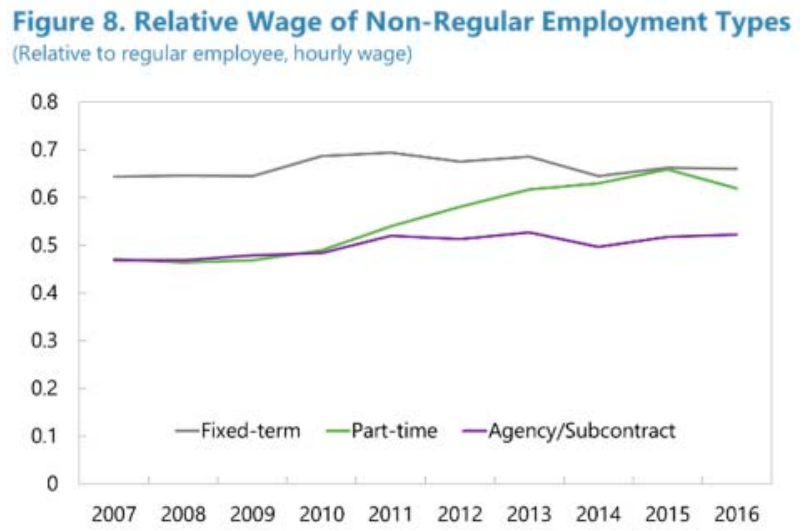

Sources: MOEL Survey on labor conditions by employment type.

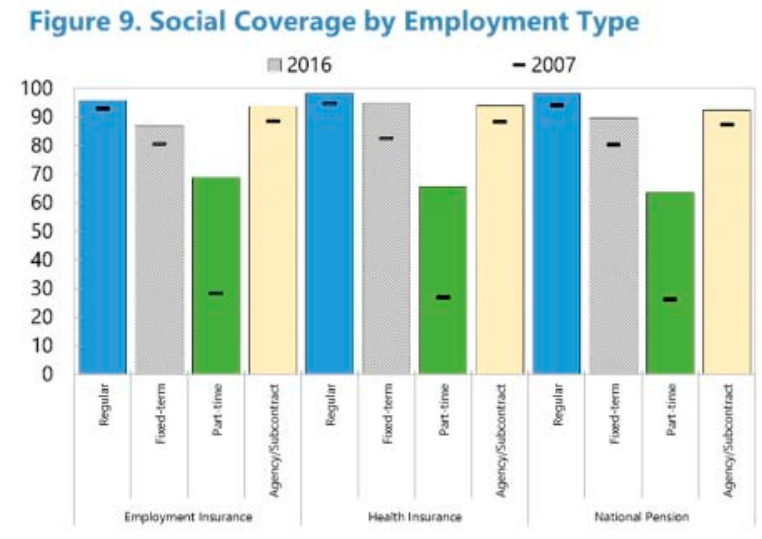

Sources. MOEL, Survey on labor conditions by employment type.

Lower wages and social coverage have been connected to negative long-run effects for non-regular workers and their families. For example, non-regular workers in Korea have lower marriage and fertility rates and spend significantly less on the education of their children. In addition, the savings rate is significantly lower for non-regular workers, which is likely contributing to the household debt problem (OECD, 2016).

Non-regular employment likely accounts for some of the income inequality observed, but inequality within employment types is also significant. While income inequality as measure by the Gini index is comparatively low in international comparison at 29.5 in 2015, it has increased compared to earlier levels observed in the 1990s. In addition, the low pay incidence was high in Korea at 23.7 percent in 2014 compared to the OECD average of 16.2 percent. ${ }^{5}$ Previous literature has found that labor market duality has worsened inequality in Korea and poverty is closely related with the status of employment (Lee, 2011; Shin, 2009; OECD, 2016). A theil-decomposition using KLIPS survey data suggests that in 2014 around 17.6 percent of overall inequality among salaried employed could be explained by inequality between regular and temporary w orkers, a slight increase from 16.8 percent in 2010 . Yet, if

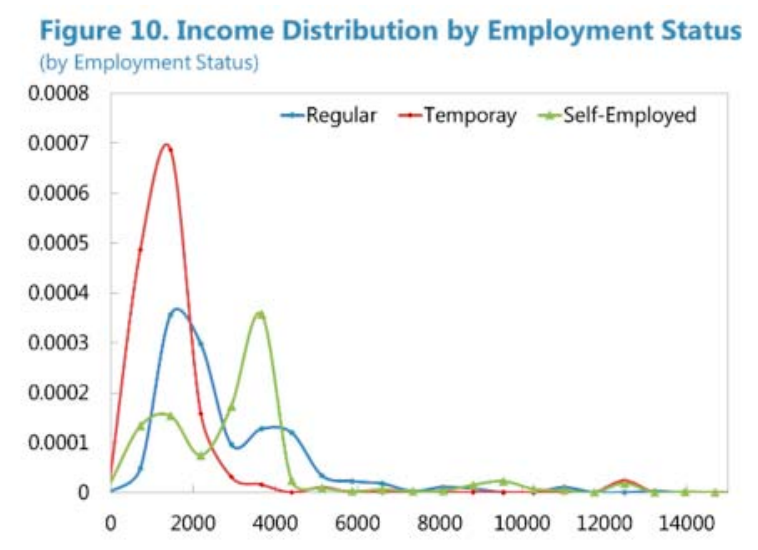
self-employed workers are added this decreases sharply to only 2 percent. This suggests that inequality within employment types is also significant, especially for selfemployed (see Table 1 and Figure 10).

Table 1. Inequality by Employment Status
\begin{tabular}{|l|c|c}
\hline & $\underline{\text { Gini }}$ & $\frac{\text { Share of Top } 10 \text { to }}{\text { Bottom } 40}$ \\
\hline Total & 0.38 & 1.65 \\
\hline Regular & 0.32 & 1.15 \\
\hline Temporary & 0.36 & 1.43 \\
\hline Self-employed & 0.44 & 2.39 \\
\hline
\end{tabular}

Sources: KLIPS, staff calculation.

Source: KLIPS, staff calculations.

\footnotetext{
${ }^{5}$ The OECD defines the low pay incidence as the share of workers that earns less than two-thirds of gross median earnings of all full-time workers.
} 
Labor market duality has created a revolving door for temporary workers, with little opportunity to attain permanent employment. Separation rates are much larger and more volatile for temporary workers compared to regular workers (see Figure 11). While only around 2.4 percent of permanent employees left their jobs in 2016, 18.8 percent of temporary and daily workers did so. Moreover, the share of permanent workers being layed off is negligible at 0.4 percent of employment, while it stood at 14.2 percent for temporary and daily workers. Annual employment flows also hint towards low mobility between nonregular and regular workers (see Table 2). Most temporary workers remain in temporary employment a year later, while only 4.8 percent obtain regular employment. Regular workers are in a much more absorbing state, with 92.5 percent remaining in their employment status.

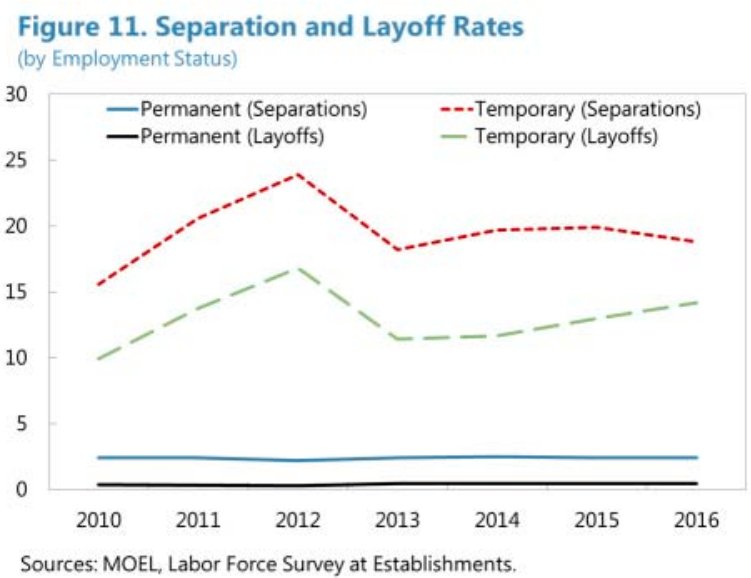

Table 2. Flow Probabilities by Employment Status (2013-2014)

\begin{tabular}{|c|c|c|c|c|}
\hline & Regular & Temporary & $\begin{array}{c}\text { Self- } \\
\text { employed }\end{array}$ & $\begin{array}{c}\text { Non- } \\
\text { employed }\end{array}$ \\
\hline Regular & $92.5 \%$ & $1.4 \%$ & $0.9 \%$ & $5.1 \%$ \\
\hline Temporary & $4.8 \%$ & $81.4 \%$ & $1.7 \%$ & $12.2 \%$ \\
\hline $\begin{array}{l}\text { Self- } \\
\text { employed }\end{array}$ & $1.3 \%$ & $2.2 \%$ & $92.1 \%$ & $4.4 \%$ \\
\hline $\begin{array}{l}\text { Non- } \\
\text { employed }\end{array}$ & $3.6 \%$ & $4.1 \%$ & $0.9 \%$ & $91.4 \%$ \\
\hline
\end{tabular}

Disadvantages and persistency of non-regular employment could be resulting in inefficient investments into education. Given the persistence and low expected income of non-regular employment, Koreans spend a lot of time and resources trying to obtain highquality regular employment (see Figure 12). This starts at a very early age with private tutoring and continues in high school to prepare for the entrance exam for higher education (College Scholastic Ability Test). This test holds high importance as it is a main determinant for which college can be attended, which in turn plays a decisive role for the type of employment that can be obtained (Kim, 2014; Eichengreen et al., 2015). For those, who are not able to secure a regular job out of college, studying for entrance exams and accumulation of certifications and diplomas often continues. While additional accumulation of human capital is usually seen as enhancing productivity and opportunities, in this case benefits of these investments have been questioned (Kim, 2015b).

Investments into on-the-job training might be inefficiently low for non-regular workers on account of the revolving door effect. Kim (2016) has found that non-regular employees receive significantly less on-the-job training. A simple regression using micro data from the OECD's PIAAC survey supports this finding: after controlling for education level, job experience and gender temporary workers still receive significantly less on-the-job trainings than permanent workers (see Table 3). While this regression is not able to control for motivation or ability these variables themselves might be endogeneous to on-the-job training and temporary employment. 

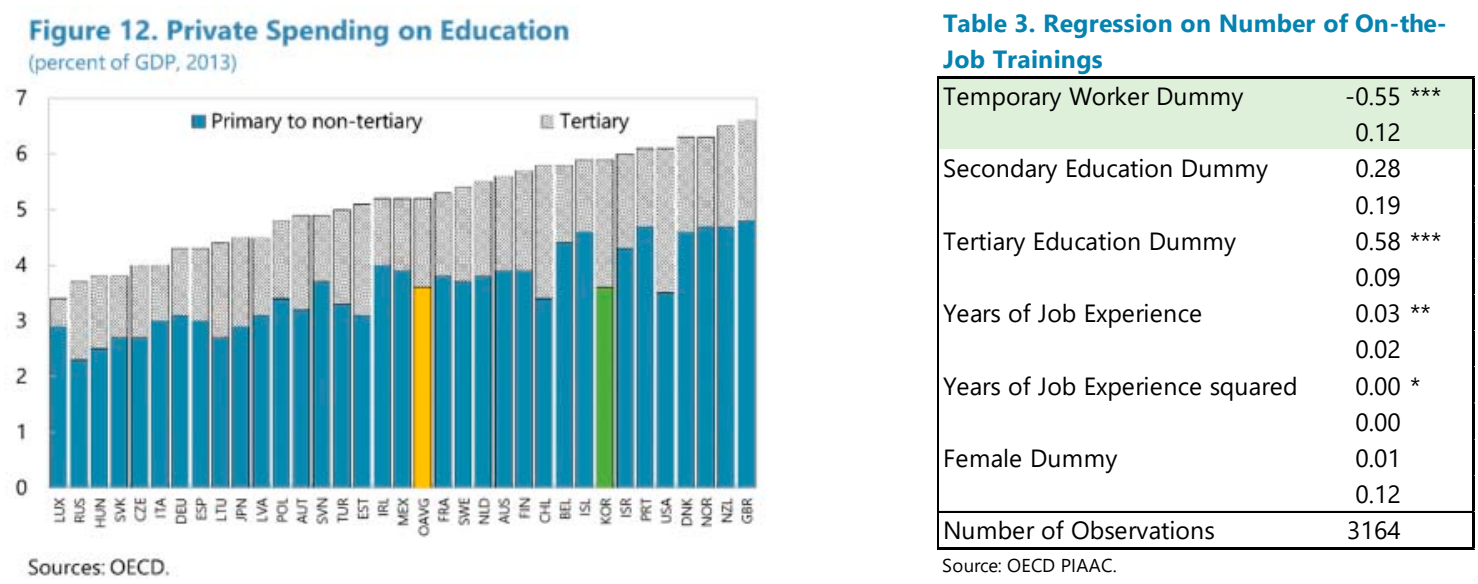

\section{What Explains Labor Market DUAlity in Korea?}

\section{Employment protection legislation}

Labor market regulation has been a significant factor behind labor market duality in Korea. Various changes to employment legislation have been attributed to shifts in nonregular employment (see Box 1). In addition, surveys suggest that firms hire non-regular workers to avoid the cost of laying off workers and benefit from lower labors costs (OECD, 2013). Three main aspects of labor market regulation are particularly relevant for Korea's duality: uncertainty and cost of dismissal, the steep schedule of mandatory severance payments, and the difference in labor costs.

\section{Korea has particularly strong} restrictions on dismissal of regular workers. The OECD EPL measures (see Figure 13) suggest that Korea has very strict dismissal regulation in international comparison. In the case of dismissal for economic reasons firms have to prove that they actively tried to avoid dismissal and have exhausted "all means" (OECD, 2013). If dismissal is on account of managerial reasons, there must be an "urgent managerial necessity", for which a clear definition is lacking (Kim, 2015a). In

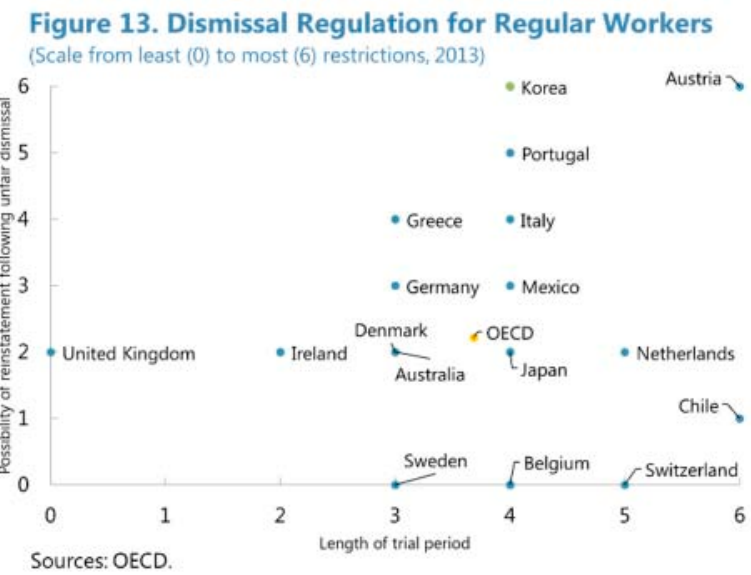
addition, dismissal above a certain number of employees has to be reported to the Ministry of Employment and Labor (MoEL) in advance (OECD, 2013). Korea has also a high frequency of reinstament orders in case of unfair dismissal. Given the unclear definitions, complex procedures and risky outcomes, costs of dismissal are high and uncertain. This has resulted in firms relying on non-regular workers to provide flexibility.

A steep schedule in severance payments and significant gap in labor costs incentivize firms to hire non-regular employees. Firms are mandated by law to pay a retirement allowance in the case of separation. It has to be paid to all full-time workers, who have been 
employed by a firm for at least a year, and is set at one month of pay for every year of work. This is a relatively steep schedule in comparison to the average of other OECD countries (see figure 14). In addition, with the seniority-based pay system that applies to a significant share of jobs, wages increase as the number of service years increases, which raises the severance payment further. These relatively large severance costs might incentivize firms to employ workers with short tenures. Recent data from the MoEL suggests that the retirement allowance was the largest component of indirect labor costs in 2015 at 44 percent. In general, labor costs are about 8 to 9 percent lower for non-regular workers due to the gap of coverage in national pension, health and unemployment insurance (OECD, 2016).

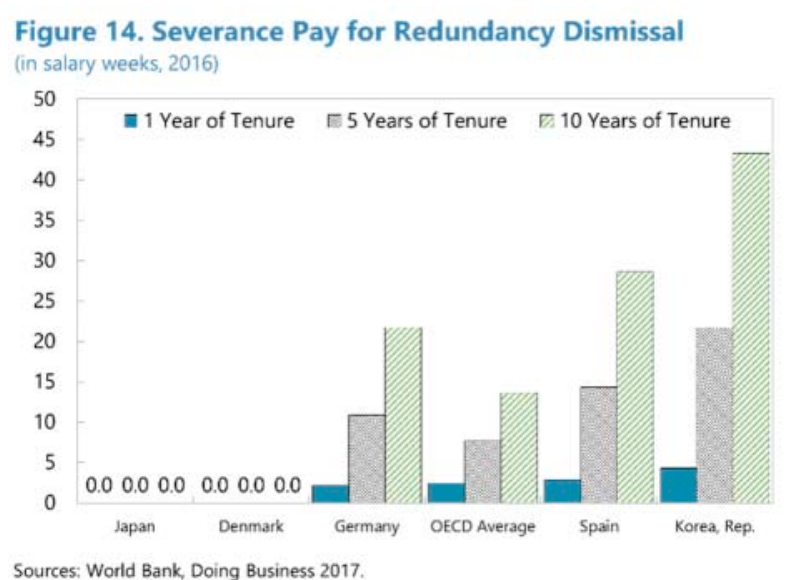

\section{Box 1. Korea-Key Labor Market Reforms}

Before the Asian crisis employees enjoyed high levels of employment protection. Korea introduced its first labor law in the 1950s and the minimum wage in 1988. However, labor regulations were not a widelydebated issue as the country was realizing an "equitable growth miracle" with high levels of employment and job protection (see Figure B1.2.). In particular, regular workers enjoyed high protection with regards to notification procedures, the definition of justified or unfair dismissal and a high possibility of reinstatement following unfair dismissal. Temporary work was very restrictive concerning the types of work for which it was allowed and the maximum duration of successive fixed-term contracts.

During the Asian crisis labor market regulations underwent significant changes under the lead of a tripartite commission. Both, regular and temporary employment regulation became significantly less strict (see Figure B1.2.). The main change for regular employees was the recognition of collective dismissal in case of "urgent managerial need". In addition, the Dispatched Workers Act was introduced, which allowed the practice of temporary work agency employment in 26 specified occupational areas. It did not set any limits on the duration of fixed-term contracts or contract renewals (Kim and Skott, 2016). At the same time, social expenditure picked up significantly from an average of 2.9 percent of GDP between 1990 to 1996 to 4.8 percent from 1997 to 2003. The increase in the flexibility of employment protection for non-regular workers during the Asian crisis has been put forth as an important driver behind
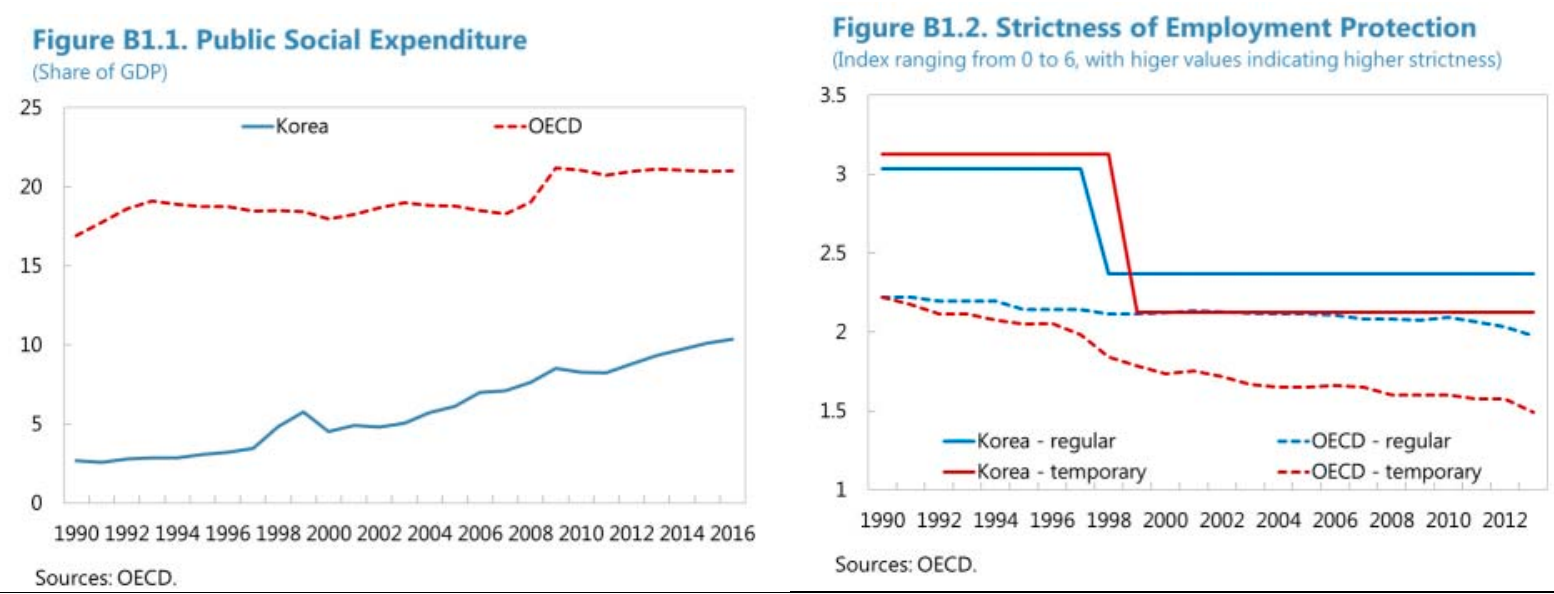
significant changes in the structure of employment, mainly an increase in the share of non-regular workers and an increasing gap in wages and benefits (Cho and Keum, 2009; Ha and Lee, 2013; OECD, 2013).

The government aimed to curb labor market duality in 2007 with the introduction of the Fixed-Term and Part-Time Employees Act and the Dispatched Employees Act. These aimed to reduce labor market segmentation by restricting the employment period for fixed-term workers to two years and prohibiting discrimination against non-regular workers, who perform similar tasks to regular workers in the same firm. However, these laws have been criticized for only applying to firms with at least five workers and very specific types of non-regular employment, which has led to avoidance behavior by firms (Cooke and Brown, 2015). In addition, it has been argued that the cap on the length of fixed-term employment has been counterproductive as firms reacted by firing and replacing temporary workers to avoid reaching the threshold (OECD, 2016). Still, around one-third of workers were converted to regular employment and some literature suggests that it has contributed to a modest decline in temporary workers (OECD, 2013; Ha and Lee, 2013).

In recent years, the Korean government has tried to improve employment protection legislation for non-regular workers. In 2012, guidelines were introduced to reduce discrimination in wages and working conditions and penalties for inadequate use of temporary agency contracts were strengthened (OECD, 2013). In addition, the Temporary Workers Act and Dispatch Workers Act were amended in 2014 to give greater protection to non-regular workers with regards to discriminatory treatment and compensation for overtime (Cooke and Brown, 2015). The regulation of regular contracts has also seen some changes, including a shortening of the notice period in case of dismissal, and replacing penal provisions with financial penalties in case of unfair dismissal (OECD, 2013). A new tripartite agreement was announced in September 2015 with one main goal being the alleviation of the dual structure of the labor market. However, critics say it later lost support from key actors (IMF, 2016a).

In addition, the government has passed various measures to enhance social insurance and union coverage for non-regular workers. In 2010 the government implemented the Trade Union and Labor Relations Adjustment Act, which introduced a framework that allows multiple unions to exist within a firm and set cost limits for union representatives that employers need to cover (OECD, 2013). Moreover, in 2011 the Comprehensive Non-Regular Workers Initiatives was introduced and included the expansion of the social insurance system, stronger enforcement of the minimum wage and vocational training for nonregular workers (OECD, 2016). Also, the Korean government did succeed in significantly increasing social care programs targeted at the vulnerable by introducing parental leave, childcare support, subsidies to the elderly and vocational training. For example, the share of social expenditure targeted at families increased from about 2.2 percent in 1998 to 11.5 percent in 2014. The government also introduced the Duru Nuri Social Insurance Subsidy Program that provides targeted subsidies to low-wage workers at small businesses for social insurance contributions (OECD, 2013).

The policy program of the new administration is also aiming to reduce duality. The new administration is aiming to address duality through three main pillars, (i) increasing households' disposable income through a higher minimum wage and expanding unemployment insurance and eligibility for basic social security recipients, (ii) promoting decent employment by restricting application of temporary contracts, reducing the legal limit of weekly working hours and introducing innovative job training, (iii) advancing fair competition between large corporations and SMEs by promoting profit sharing and removing unfair practices (MoSF, 2017).

\section{Product market segmentation}

Large labor productivity gaps between sectors and firms have likely contributed to labor market duality. A disproportionately large share of non-regular employment can be found in SMEs and the service sector (see Figures 6 and 7). Indeed, Korea has undergone 
significant structural changes with the share of employment in the service sector rising from 41 percent in 1983 to 71 percent in 2016 . Yet, productivity growth has not kept up and labor productivity in the service sector was only 45 percent of that in manufacturing - far below the OECD average of 90 percent (see Figure 15). In addition, Korea stands out on account of small firms' productivity being only 24 percent of that of large firms, compared to an OECD average of 69 percent. These large productivity gaps have likely contributed to labor market duality as low productivity firms are unable to offer high-quality regular jobs (Ha and Lee, 2013; OECD, 2013). ${ }^{6}$

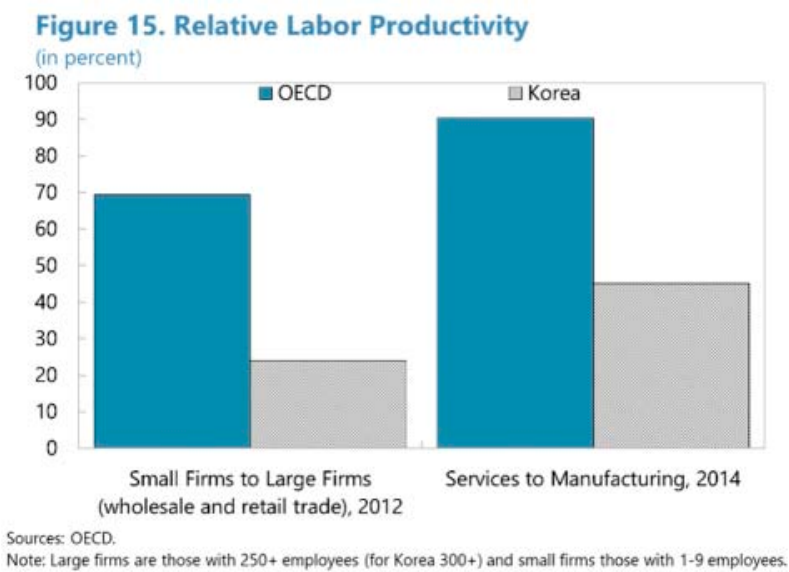

Temporary workers in SMEs face a double penalty in terms of wages, social coverage, training and job missmatch. KLIPS micro data provides a more detailed picture of the interplay of firm size and employment contracts (see Table 4). It supports the idea of "double duality" as (i) temporary employees are generally receiving lower wages and have less social coverage than regular employees and (ii) temporary workers in SMEs are worse off than temporary workers in large companies. ${ }^{7}$ There is also a clear difference in job quality for regular employees in large firms and SMEs, yet on average they are still mostly faring better than temporary workers. The data also supports the finding that regular employees receive significantly more training and are less often missmatched with their jobs in terms of educational level.

Table 4. Wages and Working Conditions by Firm Size and Employment Type (Wave 17, 2014)

\begin{tabular}{|c|c|c|c|c|c|c|c|c|}
\hline & \multirow[b]{2}{*}{ Share } & \multirow[b]{2}{*}{$\begin{array}{l}\text { Relative } \\
\text { Wage }\end{array}$} & \multicolumn{3}{|c|}{ Coverage } & \multirow[b]{2}{*}{ Training } & \multicolumn{2}{|c|}{ Missmatch } \\
\hline & & & $\begin{array}{l}\text { National } \\
\text { Pension }\end{array}$ & $\begin{array}{l}\text { Health } \\
\text { Insurance }\end{array}$ & $\begin{array}{l}\text { Employment } \\
\text { Insurance }\end{array}$ & & $\begin{array}{l}\text { Under- } \\
\text { qualified }\end{array}$ & $\begin{array}{l}\text { Over- } \\
\text { qualified }\end{array}$ \\
\hline $\begin{array}{l}\text { Regular employee } \\
\text { (large firm) }\end{array}$ & $19.4 \%$ & 1.0 & $88.8 \%$ & $95.4 \%$ & $94.5 \%$ & $18.5 \%$ & $1.1 \%$ & $5.4 \%$ \\
\hline $\begin{array}{l}\text { Regular employee } \\
\text { (SME) }\end{array}$ & $57.5 \%$ & 0.6 & $80.0 \%$ & $85.7 \%$ & $84.9 \%$ & $5.7 \%$ & $0.5 \%$ & $11.8 \%$ \\
\hline $\begin{array}{l}\text { Temporary employee } \\
\text { (large firm) }\end{array}$ & $2.0 \%$ & 0.4 & $56.4 \%$ & $57.5 \%$ & $60.2 \%$ & $7.5 \%$ & $3.0 \%$ & $24.8 \%$ \\
\hline $\begin{array}{l}\text { Temporary employee } \\
\text { (SME) }\end{array}$ & $21.2 \%$ & 0.3 & $24.2 \%$ & $31.0 \%$ & $31.7 \%$ & $3.1 \%$ & $0.4 \%$ & $27.6 \%$ \\
\hline
\end{tabular}

Source: KLIPS, authors calculations.

Notes: Large firms are those with $300+$ employees and SMEs those with 300 or less. Temporary employees include temporary and daily workers with contracts of less than one year or hired on daily or ad-hoc basis.

\footnotetext{
${ }^{6}$ In turn, a large share of non-regular workers in SMEs and the service sector could also lower productivity by reducing investments into training and innovative technologies (see discussion in section I). This suggests a vicious cycle and a need to identify underlying drivers, such as financial frictions and market structure.

${ }^{7}$ Contrary to results presented in table 4, more recent data from the Economically Active Population Survey suggests that in 2016 irregular workers in large companies had a higher wage than regular workers in small companies (IMF, 2018a). This discrepancy might be due to differences in the representativeness of the data, the year of data collection and/or the definition of irregular versus temporary or SME versus small companies.
} 
In the service sector a wage gap relative to manufacturing only exists for certain sub-sectors. Wage gaps between temporary workers in services and those in manufacturing are largest in the sub-sectors of restaurants and hotels, real estate and wholesale and retail trade (see Figure 16). Yet, in some sub-sectors temporary workers on average earn more than in manufacturing. In addition, also within sectors the wage gap between permanent and temporary employees is often significant.

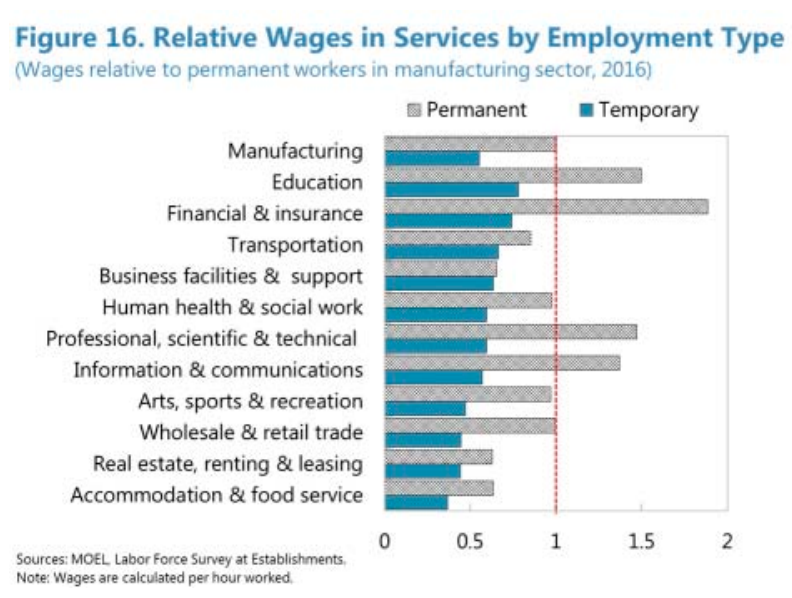

Figure 16. Relative Wages in Services by Employment Type

\section{Insider-outsider dynamics}

\section{Insider-outsider dynamics have likely exacerbated labor market duality in Korea.} Insider-outsider dynamics arise due to labor turnover costs, which give a group of employees larger bargaining power and thus the ability to negotiate better contracts compared to outsiders with regards to wages, benefits or job security. While these turnover costs are partially on account of the legal protections discussed above, they can take a plethora of forms and labor market duality due to insider-outsider dynamics can arise even in economies with flexible job protection and low union density (Lindbeck and Snower, 2002). Some evidence for insider-outsider dynamics can be found in Korea as company welfare in certain firms is significantly larger than legally required with regards to benefits and retirement allowance (OECD, 2013; Kim, 2016).

\section{While average union density is low in international comparison, it differs greatly} between employment types and firm size. Union density is low in Korea at about 10 percent, compared to an OECD average of 17 percent (see Figure 17). There are two major unions today, the Federation of Korean Trade Unions (FKTU) and the Korean Federation of Trade Unions (KCTU). Historically, labor relations have been criticized for being confrontational and cooperation in labor-management relations has been described as low (Eichengreen et al., 2015). Since 2005, the annual number of labor-management dispute

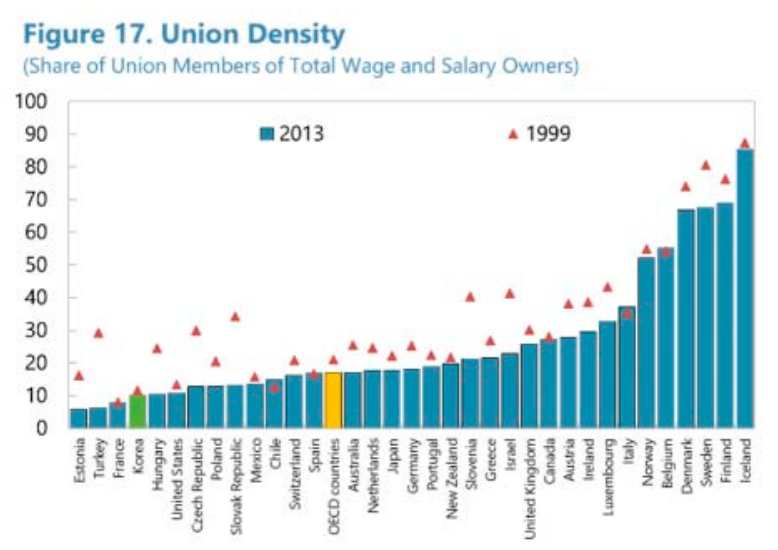

Sources: OECD

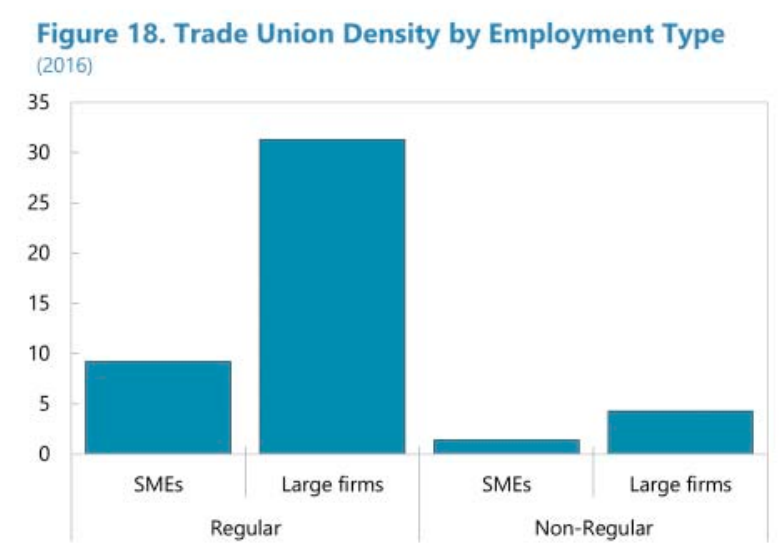

Sources: MOEL, Survey on Labor Conditions. 
cases has stabilized at around 120, but disagreements remain during wage and collective bargaining processes at some enterprises. In addition, unions have been criticized for lacking representativeness (OECD, 2013; Kim, 2016). It has been argued that they negotiate high benefits for their members (who are mainly workers in large companies), which are squeezing margins of small suppliers and thus wages of their employees (Eichengreen et al., 2015). Indeed, unions in Korea are largely representing regular workers, especially those in large companies (see Figure 18).

\section{Global trends of labor market polarization}

\section{Labor market polarization has been observed across a wide range of advanced and emerging countries and has been linked to globalization of labor markets and} technological change. A trend of polarization of labor markets - employment shifting away from middle-wage tasks towards low- and high-wage jobs - has been documented for many advanced and emerging economies (Autor, 2010; Reijnders and de Vries, 2017 and references therein). This has been attributed to middle-wage jobs often consisting of "wellunderstood, precise procedures" (Autor, 2010), which can more readily be automated (Autor et al., 2003) or outsourced (Blinder, 2009). This can reduce the middle share of employment or lower their bargaining power and wages and contribute to labor market dualities.

There exists some evidence that Korea has experienced labor market polarization. For Korea, Reijnders and de Vries (2017) did not find evidence for polarization of employment shares between 1999 and 2007. However, changes in employment shares by wage levels suggest that Korea has undergone different trends between 1993 and 2016 (Figure 19). A clear polarization took place from 1993 to 1999 with employment shares moving from medium-wage largely to high-wage occupations and a smaller share to low-wage jobs. A further polarization took place from 2009 to 2016 as employment shares moved from medium- to low-wage occupations. Wage differences have also widened in absolute terms with low-wage occupations earning on average 5 US dollar less per hour than medium-wage occupations and 10 US dollar less than high-wage occupations (see Figure 20). ${ }^{8}$
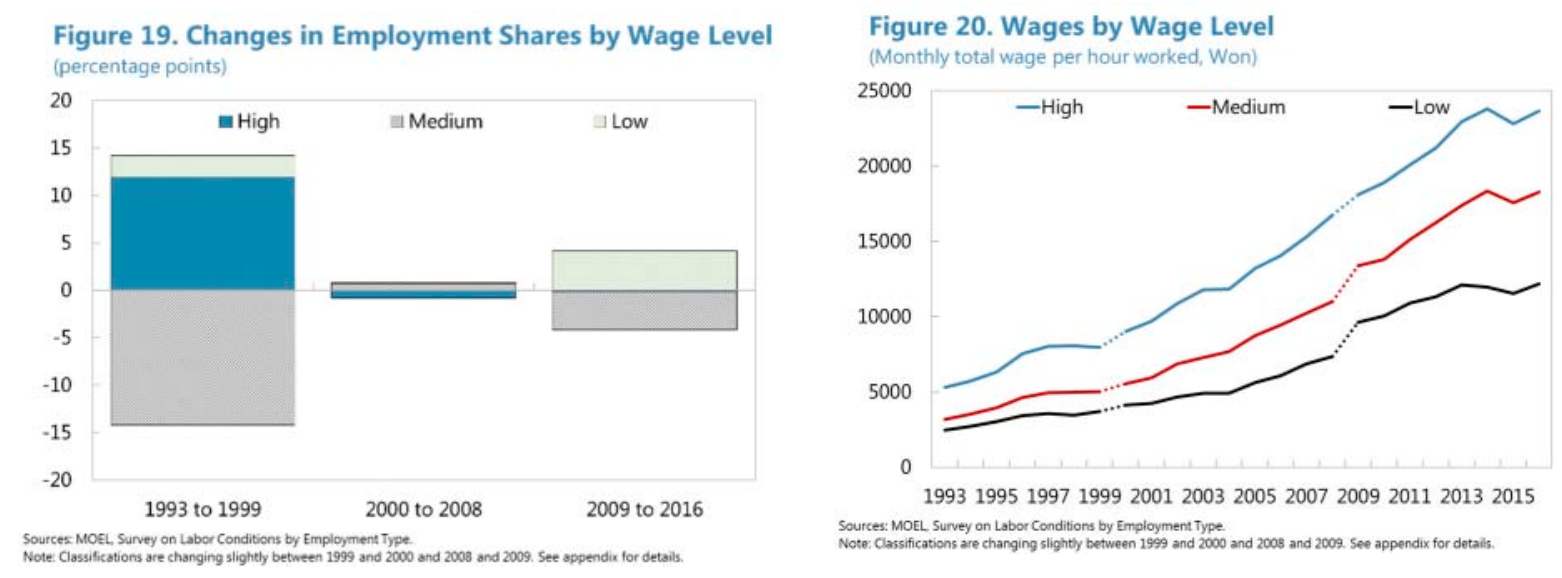

\footnotetext{
${ }^{8}$ In relative terms high wage occupations earned 1.94 times that of low wage occupations in 2016, compared to 1.88 times in 2009. However, in the period from 1993 to 1999 the relative wage fluctuated around 2.2 times, and from 2000 to 2008 it was on average 2.3 times higher. While this would suggest a long-term decline in relative wage differences, comparisons are complicated by changing classifications (see appendix A3).
} 
Automation and outsourcing might have contributed to Korea's polarization. While an in-depth analysis is needed to identify main drivers of polarization, Korea stands out as the country with the highest robot density in the manufacturing industry since 2010 with 631 industrial robots per 10000 employees in 2016 (IFR, 2017). Korea has also experienced significant integration into global value chains, including through outsourcing (IMF, 2018b). In addition, Lee and Lee (2015) find evidence that offshoring has contributed to larger wage inequality between temporary and regular workers in manufacturing sectors.

\section{Box 2. Women, Elderly and Youth-Why Does Non-Regular Work Affect Them Disproportionately?}

Women in Korea struggle to combine family responsibilities and a good career. Korea has the largest gender pay gap in the OECD at 37 percent in 2015, compared to an average of 16 percent (Figure B2.1.). However, the large pay gap cannot only be explained by the larger share of women in non-regular employment as a similar gender gap exists even within non-regular work (Figure B2.2.). In addition, Korea's female labor force participation rate is low at 58.4 percent, as women tend to leave the labor force once they have children. This is due to low flexibility of regular employment, that often demands long working hours and an uninterrupted employment relationship (OECD, 2013) when childcare is mostly shouldered by women. If women return to work after raising a child, they can often only obtain non-regular employment (Kim, 2016). However, some of them likely choose part-time jobs to have time to take care of their children. The Korean government has been promoting part-time jobs to help women achieve a workfamily balance, with around 10500 applicants in 2016.
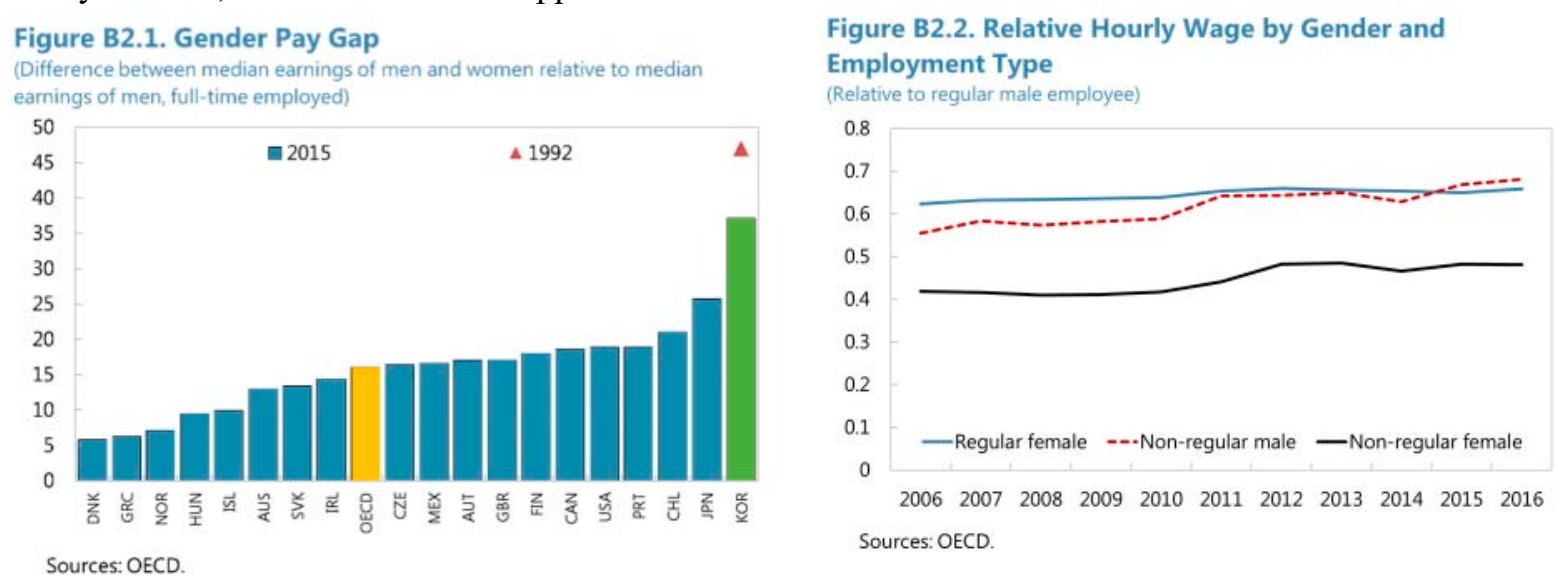

Korea's elder population is forced to retire early and pursue a second career in non-regular employment. Regular workers are often asked to retire around the age of 50 as wages and other benefits such as the retirement allowance - increase steeply with tenure (OECD, 2013). This pushes the elderly to become self-employed or accept other types of nonregular work and has likely contributed to large shares of old age poverty and high levels of household indebtedness.

As new entrants into the labor market, youth are struggling to obtain regular jobs. A higher share of youth in non-regular work could be due to natural reasons, such as higher uncertainty regarding skills and productivity of a young worker on the firm's side or uncertainty about job preferences on the side of youth. However, duality affects the young even before entering the labor market. Labor market duality and the low mobility

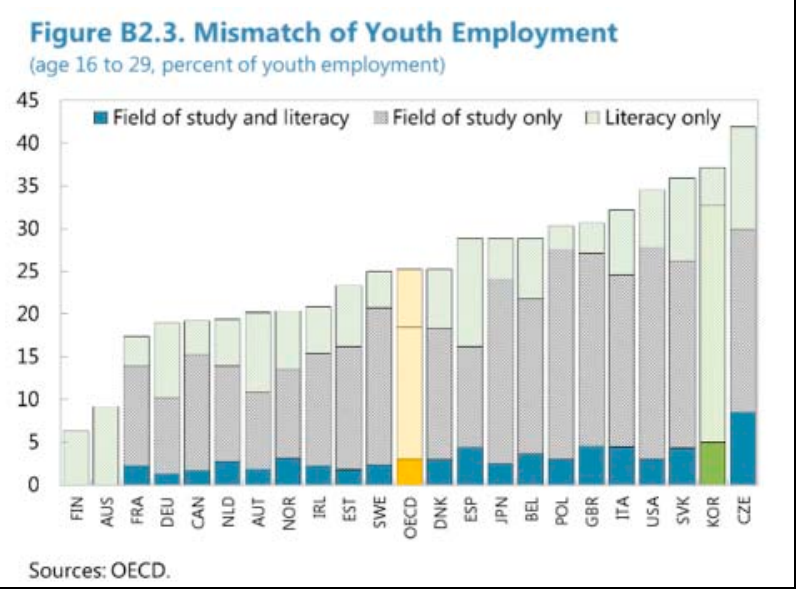


between regular and non-regular segments, has implied that the young are investing heavily in education and queue for jobs in the public sector and large companies (see IMF, 2018b). Youth also face a rising skill mismatch (see Figure B2.3.; OECD, 2013; Dao et al., 2014), which likely lowers productivity and the quality of employment. Here, a main challenge is the large education gap between the outgoing elderly population and the new highly-educated youth cohorts (OECD, 2013). The jobs left by the elderly are likely not a good match for the young.

\section{How Can Policy Address Labor Market Duality?}

\section{Labor market duality in Korea is a complex but critical issue that is of particular relevance today. Duality is an entrenched characteristic of Korea's labor market as presented in section II. And while some types of unregular employment have declined, they are still at high levels in international comparison. In addition, income inequality measures have recently increased with labor market duality likely contributing to this development (section III). At the same time, Korea's society is rapidly aging, which has resulted in declining potential GDP growth. It is thus critical to reduce labor market duality in order to raise labor force participation (in particular of the young, women and elderly) and productivity.}

Policies can play a critical role in addressing duality. The causes behind labor market duality are multifold and go beyond laws and policies, including the nature of contract negotiations and global trends reducing the bargaining power of certain workers (see section IV). Yet, the previous discussion has shown that policies have critically contributed to duality and its harmful implications for those affected. Thus, labor reforms have the potential to significantly improve Korea's labor market and give important impulses. It is also clear that measures would need to address labor as well as product markets to address "double duality". I will focus here on the side of the labor market and present and evaluate detailed policy options.

\section{Korea's policy of protecting jobs instead of workers is unlikely to inherently reduce} duality and improve labor market outcomes. Currently, the Korean labor market is characterized by protection of jobs. In particular, regular jobs are strongly protected through high dismissal cost. At the same time protection of people is lacking. Low unemployment insurance benefits force outsiders to accept low-quality and missmatched employment or give up and drop out of the labor force. Policies trying to remedy this often only act at the fringes by trying to improve low-quality jobs through subsidies. However, this approach is unlikely to inherently and sustainably improve the situation as it is not adressing the underlying drivers. Some recent policy proposals (Box 1) do promise to address underlying structural issues, but further efforts are warranted to ensure their success.

Korea should consider moving towards its own form of "flexicurity" to reduce duality and its negative effects on the economy and society. ${ }^{9}$ Labor market policies should shift towards "protecting the workers, not the jobs" by pursuing a model of flexicurity, a mix of

\footnotetext{
${ }^{9}$ Also see Byeon et al. (2017) for a similar proposal.
} 
flexibility and security (see section V.A for an explanation). This would address duality and its negative effects through various channels:

- Increasing productivity. A model of flexicurity would enhance resource allocation and thereby increase productivity (Blanchard et al., 2013 and references therein). This would allow workers to move towards the most productive jobs and ensure they would acquire the necessary training. This would likely result in better matches and thus lower product market segmentation and labor market duality.

- Raising labor force participation. A flexicurity approach is often suggested to countries wanting to reduce high unemployment rates (Zhou, 2007). While this is not generally an issue for Korea with an average unemployment rate at 3.7 percent in 2017, flexicurity could help to increase its low labor force participation rate by incentivizing inactive individuals to enter the labor market. As this would often be women, it could have a further feedback effect - by adding a second earner to families the demand for job-security among insiders might relax as implications of job loss are better cushioned.

- Preparing for structural change. Korea stands out as the country with the biggest education gap between youth and the elderly in the OECD and one of the fastest aging countries in the world. Thus, it is unlikely that the jobs the elderly are retiring from, are a good match for youth joining the labor force. It is thus critical to protect workers instead of jobs a la flexicurity to avoid large missmatches and productivity losses, which would exacerbate duality. This is even more pressing, given the global trends of technological change and integration of labor markets which call for quicker adjustments of workers to new tasks.

- Enhancing equity. A flexicurity approach would reduce the high protection granted to regular employees and adapt a smoother schedule. This would lower labor market duality and the inequalities it entails. In addition, the combination with higher unemployment benefits and activation policies would enhance job matches and protect the vulnerable, which would enhance equity and lower duality further.

\section{A. What is Flexicurity and When Does it Work?}

The flexicurity model centers around three main levers of labor market policy employment protection legislation, unemployment insurance and active labor market policies. In particular, it consists of the so-called "golden triangle" of (i) flexible rules for hiring and firing of regular workers, (ii) a strong safety net in form of unemployment insurance and (iii) active labor market policy. ${ }^{10}$ This policy mix aims to provide a necessary level of labor market flexibility, while ensuring a high level of security to the workers through social protection and active labor market policies (Zhou, 2007). The general idea is that workers should be protected more through unemployment insurance (security) than employment protection legislation (flexibility), while acknowledging that unemployment

\footnotetext{
${ }^{10} \mathrm{See}$ http://denmark.dk/en/society/welfare/flexicurity for further information.
} 
benefits can only be higher if active labor market policies ensure incentives for work are not diminished (Blanchard et al., 2013).

\section{Country examples}

\section{Denmark has a long history with flexicurity and is its leading example.} Denmark has often been used as the model student of flexicurity (Auer, 2010; Zhou, 2007; Algan and Cahuc, 2006). A crosscountry comparison illustrates the significant spending on unemployment insurance (Figure 21) and active labor market policies (Figure 23). While it has also been argued that Denmark has flexible rules for hiring and firing (Wilthagen et al., 2003; Danish Ministry of Foreign Affairs, 2017), it falls in the middle of OECD countries in the OECD indicator for strictness of employment protection legislation (Figure 22). However, this is largely due to the length of mandated notification periods and not, as in the case of Korea, complexities regarding dismissal trials.
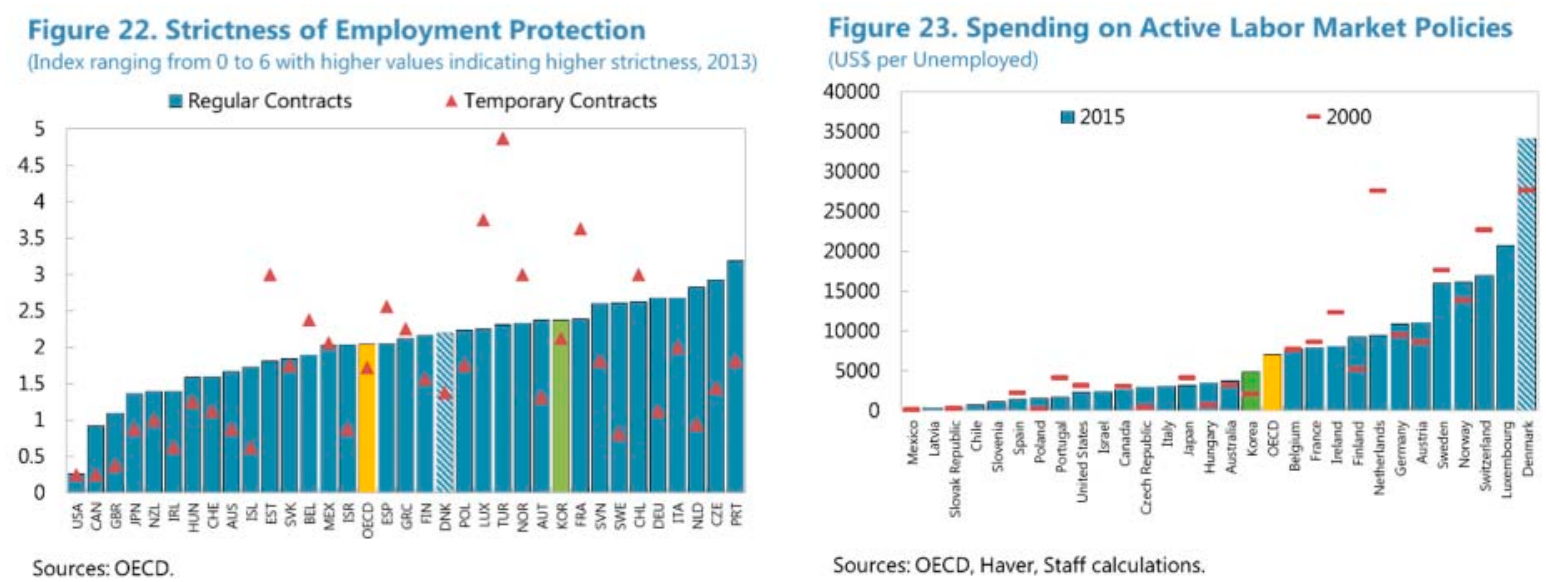

The flexicurity model in Denmark has a long history and has undergone continuous calibration to improve outcomes and adjust to emerging challenges. For example, since the late 1990s labor market reforms were introduced to increase incentives for labor force participation. These included a reduction in the maximum unemployment benefit period and expansion of mandatory "activation," which implied that those who fail to accept a job or training opportunity lose all benefits after six months (Zhou, 2007). The ability to recalibrate appears to be a critical aspect and heavily relies on the support by all social partners, in particular employers and employees. In addition, the success of the flexicurity model in Denmark has been attributed to a fundamental trust of employees towards their employers and the social safety net, flexibility within jobs to ensure a good work-life balance, an education system that fosters independent thinking and working and a strong tradition for lifelong learning (Danish Ministry of Foreign Affairs, 2017). 
Other countries have moved towards flexicurity more recently, with some promising results. For example, Austria introduced a reform of severance pay in 2003, which increased flexibility while ensuring income security. Kettemann et al. (2017) find that the reform resulted in a substantial increase in job mobility. Portugal introduced an even broader set of reforms between 2011 and 2015 that reduced severance pay and eased the definition of fair dismissal, while widening the safety net and strengthening its activation framework. In a preliminary evaluation, the OECD has called the reforms "a move in the right direction," noting that both employment and unemployment rates improved significantly and stronger than expected (OECD, 2017).

\section{Best practices}

The three pillars of flexicurity critically depend on each other and should be implemented jointly to ensure an adequate balance between incentives, support and protection. In particular, workers should be mostly protected through unemployment insurance. Employment protection through legislation should be limited and turnover costs due to judicial uncertainty should be avoided. Where there is a role for legislation it should focus on monetary transfers from the firm to the worker and should increase smoothly with tenure, avoiding jumps that can cause duality. If unemployment insurance is raised it will need to be accompanied with effective active labor market policies (Blanchard et al., 2013).

Initial conditions likely play an important role in ensuring success of reforms towards flexicurity. Various factors have been identified that increase the likelihood of success of flexicurity reforms. These include a high level of trust between firms and workers (Blanchard et al., 2013), a certain degree of "public spiritedness" of citizens (Algan and Cahuc, 2006), a low unemployment rate and a healthy fiscal position (Zhou, 2007).

\section{Continuous calibration and attention to detail are critical for successful}

implementation. The flexicurity model in Denmark has been continuously adjusted and finetuned, which appears critical for its success (Zhou, 2007; Andersen, 2017). In addition, the details of the policies implemented matter. For example, active labor market policies need to be designed carefully, adjusted to the country-specific context and continuously reassessed and revised when failing to pass cost-benefit analysis (Blache, 2011; Blanchard et al., 2013; Card et al., 2010; 2015; Crépon and van den Berg, 2016). Comparing Korea's and Denmark's spending on active labor market policies by category, shows that Korea allocates the largest share to direct job creation, while Denmark mostly spends on training and sheltered employment and rehabilitation (see Figure 24).

The right level of flexicurity should be chosen to ensure fiscal viability. Denmark spends large amounts on active labor market policy (1.7 percent of GDP in 2015) and unemployment insurance (1.1 percent of GDP), compared to Koreas comparatively low spending of 0.4 percent and 0.3 percent of GDP. This has called into question the efficiency 
of the flexicurity model as large costs might result in a high labor tax wedge ${ }^{11}$ thereby discouraging employment creation (Zhou, 2007). Additionally, costs are likely to expand significantly in times of crisis (Andersen, 2011; 2017). Thus, it is critical to find an adequate balance between flexibility and security, maintain a high employment rate and ensure that the tax wedge does not widen excessively. For example, Denmark has begun to reform the social safety net to strengthen labor supply including measures targeting the elderly, young, and immigrants (Andersen, 2017). It also reduced its tax wedge since 2000 (see Figure 25) and is now close to the OECD average. Korea's tax wedge is comparatively low.
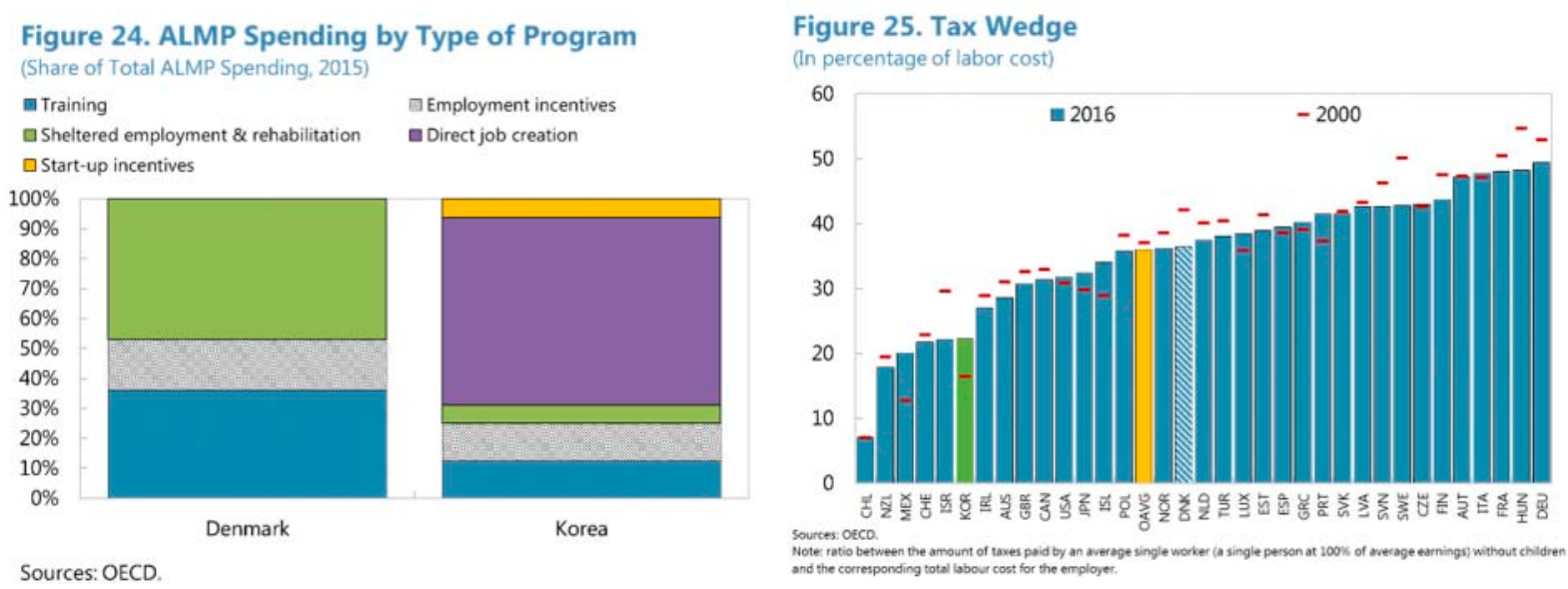

\section{B. A Model of Labor Market Duality}

A general equilibrium search-and-matching model is applied to model duality and test the impact of flexicurity policies. In this model, based on Dolado et al. (2017), labor market duality and unemployment arise endogeneously on account of employment protection legislation and search-and-matching frictions. The type of duality focuses on that between temporary and permanent workers and accounts for differences in wages and job security. In addition, the 'revolving door' arises endogenously as employment protection legislation jumps after a certain amount of tenure in a job. The model also accounts for the positive aspect of severance pay and job security as individuals are risk averse and have only partial private insurance. This implies that workers value the protection and insurance aspects of severance pay and dismissal costs. After calibrating the model to the Korean economy in section $\mathrm{C}$, I analyze the impact of flexicurity policies in section $\mathrm{D}$.

Demographics and Utility. The model has a continuum of individuals of measure one, who are either young or old. The young become old with a probability $\gamma$ and the old retire with probability $\chi$. All individuals receive utility from consumption and are risk averse:

$$
u\left(c_{t}\right)=\frac{c_{t}^{1-\eta}-1}{1-\eta}
$$

\footnotetext{
${ }^{11}$ The tax wedge, as a percentage of labor costs, is measured by taking the total taxes and social security contributions paid by employees and employers, minus family benefits received as a proportion of the total labor costs for employers.
} 
where $\eta>0$ is the coefficient of relative risk aversion. They maximize their life-time utility and discount the future at interest rate $r$. This implies that in combination with imperfect asset markets there is a role for severance pay and firing costs to insure workers. Individuals are in one of two states - they are either working for a firm and earning a wage or they are unemployed. These states arise endogenously as the unemployed can match with firms and become a worker, while the employed might separate from their jobs. However, only the young unemployed are assumed to keep searching, while the elderly are assumed to remain unemployed once they lost their job. This is a simplification, but proxies the difficulty of finding a new job at an old age.

Workers. There exists a continuum of firms that each have one job. A worker in this job provides one unit of labor. Production takes the form:

$$
Y_{t}=z_{t}
$$

where $z_{t}$ is the idosyncratic productivity of the firm-worker-match. Each initial match starts at the same initial level of productivity $z_{0}$ and follows and auto-regressive process in the following periods, with persistency $\rho$ and variance $\sigma$. In addition, a worker is characterized by her tenure $\tau$, i.e. the number of periods she has worked in the current match. She receives a wage, which is the outcome of Nash bargaining in each period. In case of separation, the firm pays severance pay $S$ to the worker, which is a function of $\tau$. In addition, the firm has to pay a firing cost $k_{f}$, which is sunk and represents other labor turnover cost, such as complex and uncertain procedures of dismissal.

Unemployed. In case of unemployment, the individual receives unemployment benefits from the government, with the amount depending on whether she is young $\left(b_{y}\right)$ or old $\left(b_{o}\right)$. If she was previously employed and eligible for severance pay, she receives a transfer from her employer at the time of separation. However, the model does not allow for saving and only provides a partial private insurance vehicle. The worker purchases an annuity with her severance pay, that pays per period:

$$
a^{i}(\tau)=\frac{1}{1-(1+r)^{\lambda^{i}}} \frac{r}{1+r} S(\tau), \quad \tau=1, \ldots T ; i \in[y, o] .
$$

Here $\lambda^{o}$ is the expected number of periods until an old unemployed retires and $\lambda^{y}$ is the expected duration of joblessness for a young unemployed. This annuity payment stops as soon as an unemployed is matched with a firm.

Search-Matching Frictions. Workers and firms match randomly. Firms have to pay a vacancy $\operatorname{cost} k_{v}$ for posting a vacancy. The number of matches is determined by a CobbDouglas function:

$$
m\left(u_{t}, v_{t}\right)=A u_{t}^{\psi} v_{t}^{1-\psi}
$$

where $u_{t}$ is the number of job-seekers and $v_{t}$ the number of vacancies. The model only allows for unemployed individuals to search for jobs, thus there is no on-the-job search.

Government. The government has two main policy levers. First, it provides unemployment benefits through payments $b_{y}$ and $b_{o}$. It finances these through a pay-roll tax $\kappa$. Second, the government sets the severance pay schedule $S(\tau)$ and firing costs $k_{f}$. 
Steady-State Equilibrium. I am analyzing the steady state equilibrium of the model, which has four main charateristics. First, firms and individuals optimize their value functions (i.e., the sum of their current utility and expected future utilities) through separation decisions and wage bargaining. Second, free entry of firms ensures the labor market is in balance. Third, the government budget is balanced. Finally, the distribution across individuals characterized by state of employment, tenure and productivity - is time-invariant.

\section{Calibration to the Korean Economy}

A set of parameters is set externally. I follow Dolado et al. (2017) and set a number of parameters externally following the convention in the literature (see Table 5). I also apply their definition of the young being aged 25 to 54 and the elderly age 55 to 64 . Periods are quarters and tenure is capped at 120.

Table 5. Parameters for Calibration

\begin{tabular}{|lcc|lcc|}
\hline \multicolumn{1}{|c|}{ Description } & Parameter & Value & Description & Parameter & Value \\
\hline \multicolumn{1}{|c}{ - Calibrated Externally } & & & \multicolumn{2}{c|}{ - Calibrated Internally - } \\
Interest rate & $r$ & 0.01 & Matching function & $A$ & 0.40 \\
Risk aversion & $\eta$ & 2 & Vacancy cost & $k_{v}$ & 0.20 \\
Ageing probability & $\gamma$ & $1 / 120$ & Cost of firing & $k_{f}$ & 3.50 \\
Retirement probability & $\chi$ & $1 / 40$ & Unemployment income, young & $b_{y}$ & 0.15 \\
Cap on tenure & $T$ & 120 & Unemployment income, old & $b_{o}$ & 0.05 \\
Matching function & $\psi$ & 0.5 & Exogeneous separation & $\delta$ & 0.005 \\
Bargaining power & $\beta$ & 0.5 & Initial productivity & $z_{0}$ & 0.29 \\
& & Persistency of productivity & $\rho$ & 0.99 \\
\end{tabular}

The severance pay schedule is based on Korean employment legislation. According to Korea's employment legislation all workers are eligible for severance pay if they held their job for at least one year, independent of the reason for dismissal. The mandatory minimum is one month of pay for each year of employment. There is thus no severance pay in the first three quarters of employment, followed by a linear increase (see Figure 26, purple line). I also add further turnover costs, which represent e.g., uncertainty and complexity of dismissal procedures. These are paid by the firm, but do not accrue to workers (see Figure 26, blue line). These costs only arise if the worker is a regular worker. The threshold between temporary and regular workers is thus set at a tenure of two years, as this is the maximum length a temporary contract can last in Korea. ${ }^{12}$ After two years of employment a temporary

${ }^{12}$ This model does not allow firms to match with a worker and directly offer her a regular contract. Thus, all regular workers in the model were temporary workers in the beginning. This assumption simplifies the solution. Aspects of the Korean labor market that support this assumption are the regulation that mandates temporary contracts to turn into permanent contracts after two years and a high share of temporary hires in all hires (around 53 percent). 
contract automatically becomes a permanent contract according to Korean employment legislation, which is also the case in this model. Thus, there are two kinks in the turnover cost schedule for firms, but only one for the worker. The severance pay schedule takes the following form for workers:

$S_{W}(\tau)=\left\{\begin{array}{c}0, \text { if } \tau<4 \\ \frac{30}{365} \times \widetilde{w} \times \tau, \text { if } 4 \leq \tau\end{array}\right.$

and the following form for firms:

$\emptyset_{W}(\tau)=\left\{\begin{array}{l}0, \quad \text { if } \tau<4 \\ \frac{30}{365} \times \widetilde{w} \times \tau, \quad \text { if } 4 \leq \tau<9 \\ \frac{30}{365} \times \widetilde{w} \times \tau+k_{f}, \quad \text { if } \tau \geq 9 .\end{array}\right.$
Figure 26. Severance Pay Schedule and Firing Cost

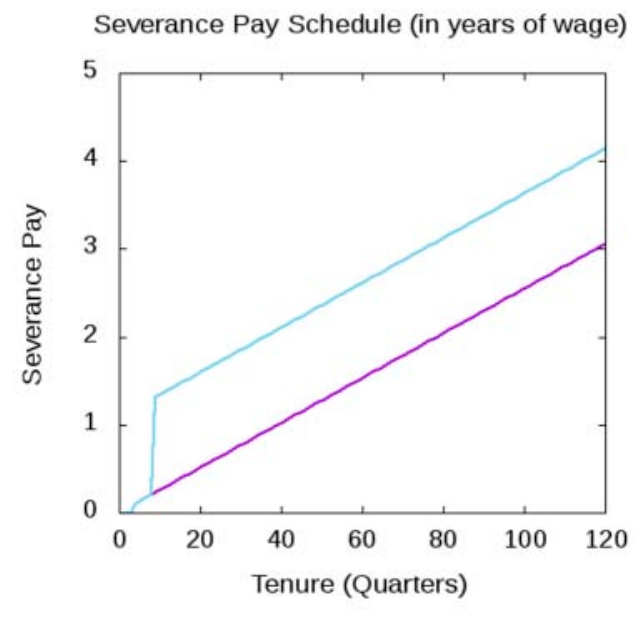

Here, $\widetilde{w}$ is the average annual wage in the economy and the level of firing costs is calibrated endogenously.

Table 6. Moments for Calibration

\begin{tabular}{|llcc|}
\hline Moment & Source & Target & Model \\
\hline Job-finding probability & Kim and Lee (2014) & 0.59 & 0.62 \\
Replacement rate, young & OECD & 0.38 & 0.45 \\
Replacement rate, old & OECD & 0.13 & 0.23 \\
Fraction of quits (in separations) & Labor Force Survey at Establishments & 0.48 & 0.47 \\
Ratio of job destruction rates & Labor Force Survey at Establishments & 7.88 & 7.91 \\
(temporary to permanent) & Economically Active Population Survey & 6.60 & 3.21 \\
Unemployment rate, young & Economically Active Population Survey & 11.60 & 20.27 \\
Unemployment rate, old & & 1.53 & 1.34 \\
Relative wage (permanent to & Survey on labor conditions & 1.15 \\
temporary) & Survey on labor conditions & 1.54 \\
Relative wage (young to old) & Labor Force Survey at Establishments, & $11.2,33.6]^{1}$ \\
\hline
\end{tabular}

${ }^{1}$ Estimates of the share of temporary workers vary widely due to the scope of workers covered in the surveys and the differences in understanding between employees and employers regarding the status of workers. The Labor Force Survey is conducted at workplaces (labor demand) who have more than one employee in the non-agricultural sector, whereas the Economically Active Population Survey is carried out at households (labor supply) covering the entire scope of workplaces of all industries and sizes.

The remaining parameters are calibrated by matching selected moments of the model

to the data. I calibrate the remaining parameters from Table 5 to match a selected set of moments from Korean data (see Table 6). I take the monthly job-finding probability from Kim and Lee (2014) and transform it into the quarterly equivalent. I calculate the replacement rate for the young by taking the average between the net replacement rate for the initial phase of unemployment and the average over 5 years from the OECD. For the replacement rate for the young, I follow Dolado et al. (2017) and assume that they can draw 
on regular unemployment benefits for two years and then fall back on social assistance, which are far less generous at 6 percent of average earnings (OECD, 2015). I also try to match fraction of quits in separations and the ratio of job destruction rates of temporary to permanent employees, where temporary workers are defined as those with a tenure of two years or less. For the unemployment rate I include the rested in the pool of unemployed, as the behavior of the unemployed elderly in the model also corresponds to those who are inactive. To account for income differences I am also targeting relative wages between permanent and temporary and young and old workers. I also include the share of temporary workers as a moment, however different data sources provide a large range of estimates for this number.

The calibrated model is able to capture main aspects of duality in Korea. The calibrated model produces a revolving door effect in the shape of a significant spike in job-destructions just before temporary workers would enter into permanent employment and become subject to the protection of firing cost (Figure 27). In addition, temporary workers are accepting lower wages (Figure 28) due to significantly lower bargaining power and the possibility to be retained as a permanent worker in the future. On the other hand, the wage profile of regular workers increases with tenure as employees gain bargaining power through accumulation of severance pay benefits. Older workers accept lower wages compared to younger workers as they do not have the possibility to search for new employment once layed off.

Figure 27. Share of Job-Destruction by Tenure

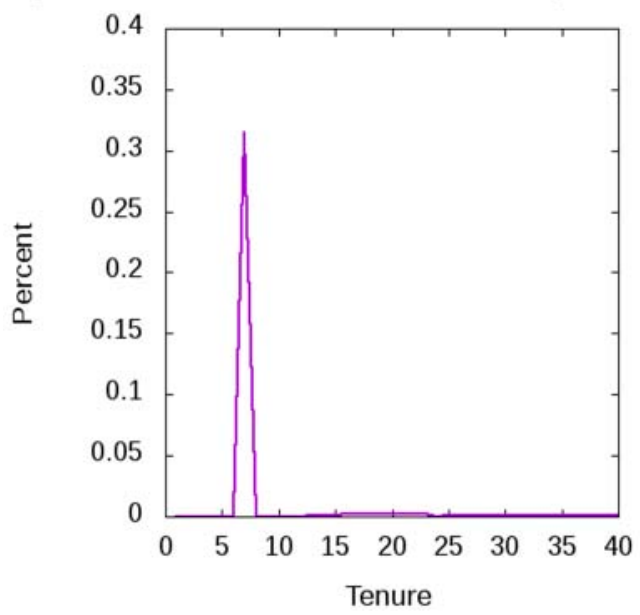

Figure 28. Wage by Tenure

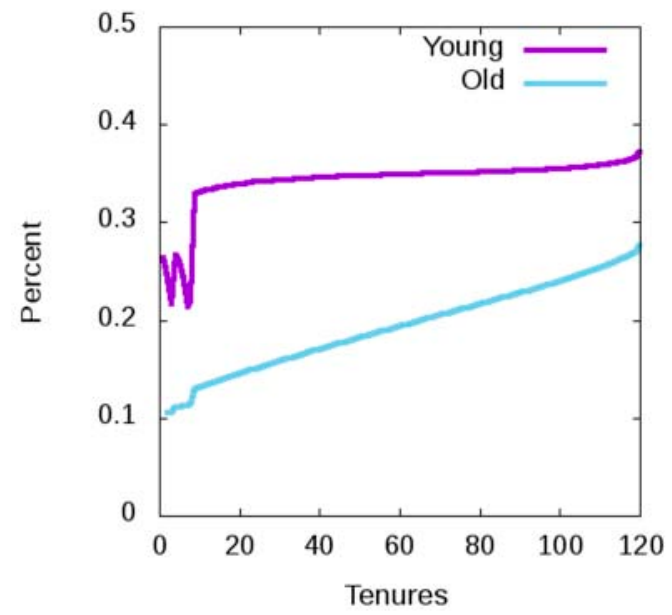

\section{Putting Flexicurity to the Test}

I use the model to analyze the impact of a move towards flexicurity on duality, welfare and income. As discussed in section A flexicurity consists of three main pillars. I model an introduction of the first pillar - a move towards more flexible hiring and firing - through a decline in the firing costs $k_{f}$. The second pillar of a stronger safety net is introduced through an increase in unemployment benefits $b_{y}$ anf $b_{o}$. Finally, I interpret active labor market policies as measures that enhance matching and provide training. Thus, I model them as an increase in the productivity parameter $A$ in the matching function and an increase in the productivity of initial matches $z_{0}$, assuming that training will increase productivity of 
individuals. I begin by introducing each pillar separately to understand their individual effects. Finally, I introduce the full package of flexicurity. Table 7 provides main results of all experiments.

Table 7. Policy experiments

\begin{tabular}{|lcccccc|}
\hline & Baseline & $\begin{array}{c}\text { Decrease in } \\
\text { Firing Cost }\end{array}$ & UI Increase & $\begin{array}{c}\text { Increase } \\
\text { Matching }\end{array}$ & $\begin{array}{c}\text { Increase } \\
\text { Training }\end{array}$ & $\begin{array}{c}\text { Flexicurity } \\
\text { Package }\end{array}$ \\
\hline Unemployment rate & $7.50 \%$ & $6.90 \%$ & $7.80 \%$ & $7.00 \%$ & $7.30 \%$ & $6.70 \%$ \\
Output & 1.00 & 1.00 & 1.00 & 1.01 & 1.08 & 1.09 \\
Average Productivity & 1.00 & 1.00 & 1.00 & 1.00 & 1.08 & 1.08 \\
Average Income & 1.00 & 1.01 & 1.00 & 1.02 & 1.08 & 1.11 \\
Average Welfare & 1.00 & 1.00 & 1.02 & 1.03 & 1.08 & 1.12 \\
$\begin{array}{l}\text { Relative job-turnover } \\
\text { (temp to perm) }\end{array}$ & 7.50 & 2.29 & 7.50 & 7.50 & 8.00 & 4.29 \\
$\begin{array}{l}\text { Relative wage } \\
\text { (temp to perm) }\end{array}$ & 0.75 & 0.83 & 0.75 & 0.71 & 0.77 & 0.87 \\
Income Gini & 16.1 & 15.4 & 15.6 & 16.6 & 16.3 & 15.0 \\
\hline
\end{tabular}

\section{Pillar I: Firing cost}

Lowering firing costs significantly reduces the revolving door effect, but only benefits the poorest. I begin by lowering the cost of firing significantly by about 60 percent. This measure reduces the revolving door effect markedly by lowering job-destruction among temporary workers (see Figure 29) and raising their wage relative to permanent workers (see Table 7). It thereby reduces inequality and the unemployment rate. ${ }^{13}$ The latter is due to less turnover of temporary workers, who thus spend less time in unemployment. Overall, average measures of income, welfare and productivity ${ }^{14}$ remain largely unchanged as does total output (Table 7). However, a closer look at the distribution of income and welfare effects suggests that there are winners and loosers of the reform. Income gains accrue to the bottom 40 percent of the income

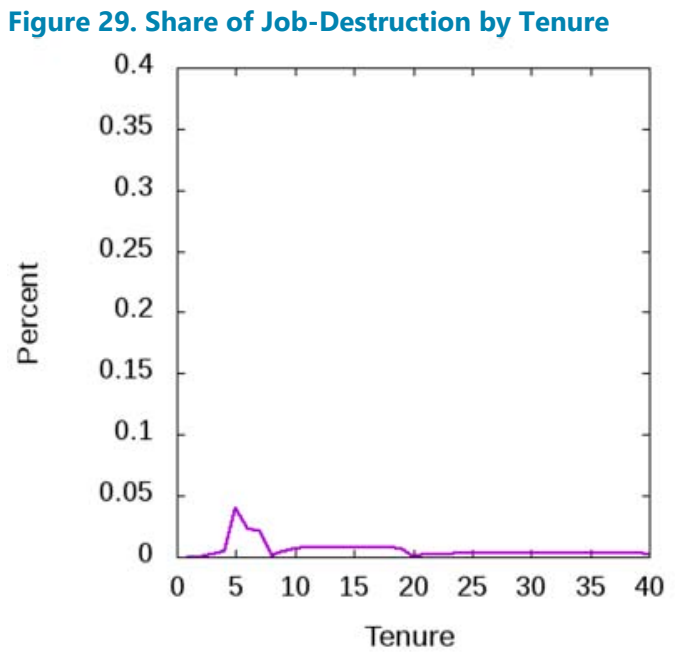

\footnotetext{
13 The decline in the unemployment rate should be interpreted as a long-run outcome because this exercise compares steady-state equilibria. In the short run unemployment could rise as firms dismiss low-productivity permanent workers immediately, while hiring of new workers might take time, in particular if done during a recession (IMF, 2016b). In addition, the overall impact on unemployment depends on the size of the initially calibrated revolving door effect.

${ }^{14}$ Note that the model does not account for inefficiencies because of the revolving door such as e.g., lower onthe-job training. This result should thus be interpreted as a lower bound on the effect of productivity.
} 
distribution (Figure 30), especially the young as they are more likely to be temporary workers. The upper 40 percent are instead loosing some income. With regards to welfare the picture looks bleaker (Figure 31). Only the bottom 20 percent of the welfare distribution gain, while the remaining parts of the population loose on account of lower job security and income. While effects on income and welfare balance on average, large shares of the population would be worse off.
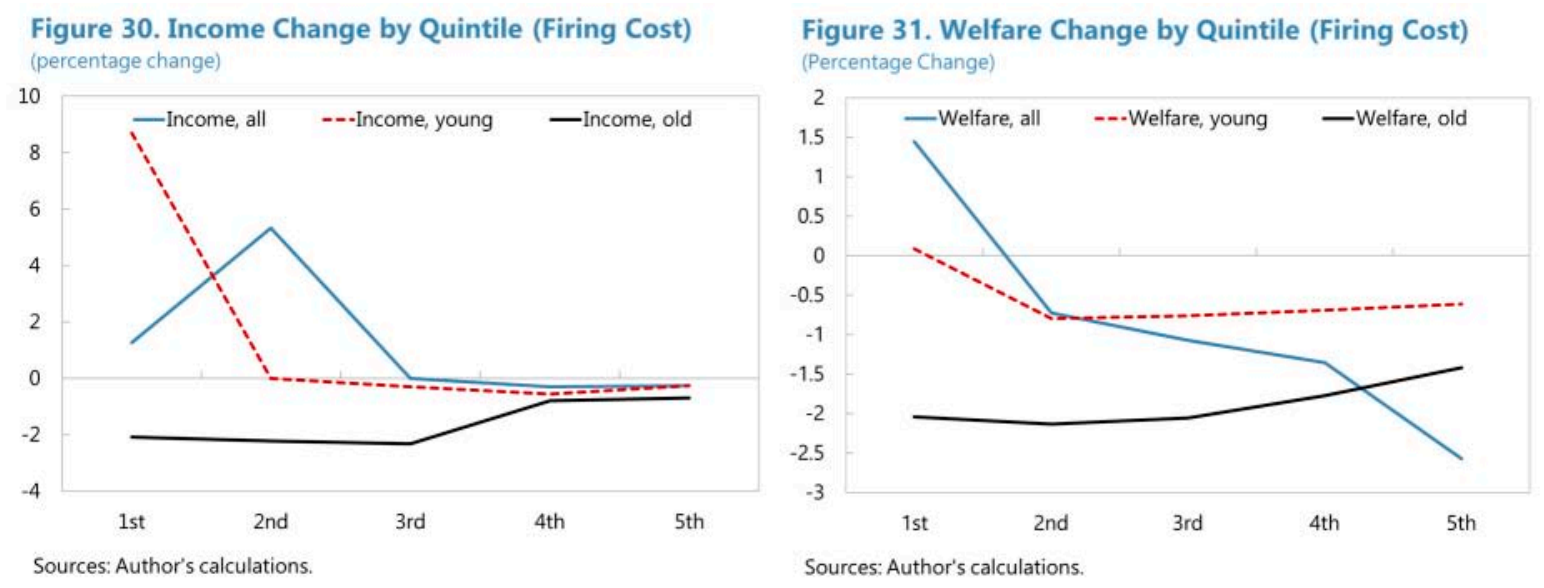

Pillar II: Social safety net

Increasing unemployment benefits can significantly lower inequality, but has no effect on duality and can exacerbate unemployment. I increase unemployment benefits moderately by 15 percent, which is around the increase necessary to raise Korea's net replacement rate to the OECD average (see Figure 21). This measure is not able to reduce duality in any way and has no significant impact on the level of productivity, output or average income (see Table 7). However, it does raise welfare. It also lowers inequality as measured by the Gini coefficient. It also increases the unemployment rate as it raises individuals' incentives to remain unemployed. Hence, an introduction of unemployment benefits by itself can only address concerns of inequality and bears the risk to induce higher unemployment rates.

\section{Pillar III: Active labor market policies}

Enhancing matching can contribute to higher income and welfare, but might exacerbate inequality between temporary and permanent workers. An increase in the matching productivity by 20 percent, increases output, income and welfare through lowering the unemployment rate (see Table 7). However, it has no effect on the revolving door effect and even exacerbates inequality through widening the wage gap between temporary and permanent workers. This is because as the probability of a match becomes more likely, firms are more ready to separate from a current worker-match and post a new vacancy. Thereby, improving job matching without reducing duality can have adverse effects on temporary workers. In addition, this model does not account for the cost of this policy, which can be substantial (see section V.A). If financed through pay-roll taxes it could have a negative effect on labor demand and thus needs to be carefully calibrated. 
Training that raises the initial productivity of matches can significantly increase output, productivity and income but has the potential to worsen the revolving door effect. I interpret the impact of training as raising the productivity of the initial match $z_{0}$. Raising the productivity by 10 percent has the strongest impact out of all policy measures on output, productivity, income and welfare (see Table 7). However, it also exacerbates the revolving door effect and raises inequality. This is on account of training raising the productivity of the applicant pool. It thus increases the incentive for firms to separate from temporary workers before they enter permanent status and replace them with a new applicant. Again, the model does not account for the costs of this measure and thus effects on income, unemployment and welfare should be seen as an upper bound.

Moving towards flexicurity - implementation of three pillars

Introducing all three pillars of flexicurity can reduce duality, lower inequality and raise income and welfare for all groups of the economy. For the final step, I introduce all three pillars (corresponding to four measures). This package raises output and average productivity, income and welfare significantly (see Table 7). In addition, it lowers the revolving door effect (see Figure 32) substantially and reduces the wage gap between temporary and permanent workers. It also lowers income inequality as measured by the Gini coefficient. A distributional analysis shows that a well-calibrated flexicurity package is able to raise income (Figure 33) and welfare (Figure 34) across all quintiles in the distribution, young and old. Hence, the combination of the measures would be able to improve economic and social outcomes across all dimensions, while individual implementation of only one pillar would likely carry some negative side-effects.
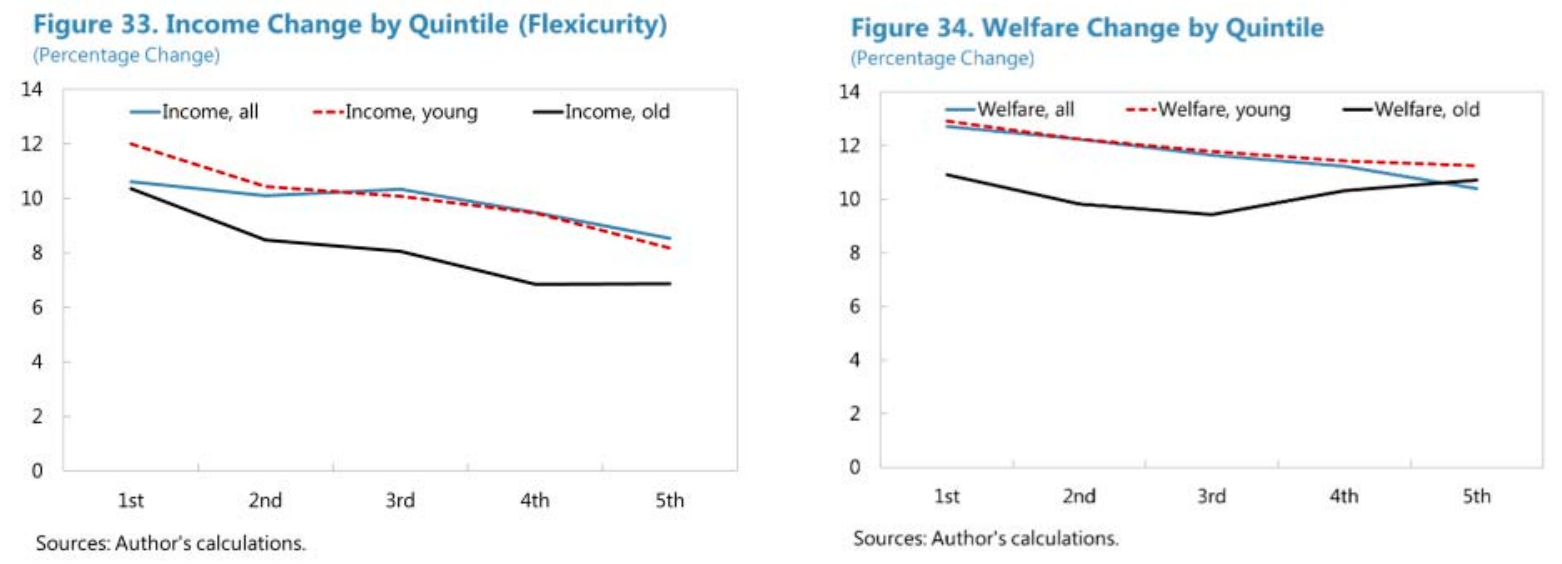


\section{Conclusion}

Labor market duality in Korea is a complex issue, which encompasses various types of non-regular workers. Nonetheless, it is particularly prominent among SMEs and in the service sector and disproportionately affects women, the elderly and youth. On a macro level it has likely contributed to increasing inequality, low fertility rates and declining productivity growth. Two key drivers behind duality are employment protection legislation and large productivity differentials in the product market. However, other factors such as insideroutsider dynamics and global trends such as globalization of labor markets and technological progress are also likely contributing.

Korea should consider implementing its own version of flexicurity. A literature and model analysis has shown that a well-calibrated introduction of flexicurity could address a number of issues that Korea is facing, such as reducing duality and inequality, and raising productivity and welfare. For this it would be crucial to implement all three pillars to ensure gains are distributed among all individuals. Yet, as the country examples have shown such a reform would need further important components, such as flexibility at the intrinsic margin (i.e., flexible jobs to ensure they fit the heterogenous needs of individuals), an education system teaching responsibility and independent thinking and a culture of life-long learning. In particular, trust and ownership by all social partners are critical, with all stakeholders part of the social dialogue, including non-unionized workers, SMEs and the self-employed.

Measures need to be carefully designed and targeted, gradually implemented and constantly revised. While the model is a clear simplification, each of the three pillars can be implemented in manifold ways. For example, unemployment benefits can be increased, expanded or extended in various ways. Rigidity in regular contracts can be reduced through reducing complexity and uncertainty in dismissal procedures or adjusting severance pay to a smoother schedule. In particular, there exist many different active labor market policies and various evaluations have shown the importance of careful design and targeting (Card et al., 2010; Card et al., 2015). For Korea, it will be particularly important to consider women, youth and the elderly in policies to ensure that their specfic issues are addressed.

Future research would benefit from additional modelling exercises. In particular, it would be important to expand the model in section $\mathrm{V}$ to an analysis of transitional dynamics to capture short-term effects of reforms. Furthermore, an explicit modelling and calibration of costs of active labor market policies would be useful. Finally, intergration of other issues such as the seniority-based wage system, product market segmentation and the minimum retirement age would enrich the analysis. 


\section{References}

Algan, Y., and P. Cahuc, "Civic Attitudes and the Design of Labor Market Institutions: Which Countries Can Implement the Danish Flexicurity Model?," IZA Discussion Paper No. 1928.

Andersen, T., 2011, “A Flexicurity Labour Market in the Great Recession: The Case of Denmark," Discussion Paper Series, Forschungsinstitut zur Zukunft der Arbeit, No. 5710.

Andersen, 2017, “The Danish Labor Market, 2000-2016”, IZA World of Labor 2017: 404.

Aoyagi, C., and G. Ganelli, 2013, “The Path to Higher Growth: Does Revamping Japan's Dual Labor Market Matter?” IMF Working Paper, WP/13/202.

Auer, P., 2010, "What's in a Name? The Rise (and Fall?) of Flexicurity," Journal of Industrial Relations, Volume 52, Issue 3, pp. 371-386.

Autor, 2010, “The Polarization od Job Opportunities in the U.S. Labor Market. Implications for Employment and Earnings," Paper released by The Center for American Progress and The Hamilton Project.

Autor, D., R. J. Murnane, and F. Levy, 2003, "The Skill Content of Recent Technological Change: An Empirical Exploration,” Quarterly Journal of Economics 118 (4), pp. 1279-1334.

Bentolila, S., and J. Dolado, 1994, "Labour Flexibility and Wages: Lessons from Spain," Economic Policy, V.9, No.18, pp. 55-99.

Blache, G., 2011, “Active Labour Market Policies in Denmark : A Comparative Analysis of Post-Program Effects", CES Working Paper.

Blanchard, O., Jaumotte, F., and Loungani, P., 2013, "Labor Market Policies and IMF Advice in Advanced Economies During the Great Recession," Staff Discussion Note, $\mathrm{SDN} / 13 / 02$.

Blanchard, O., and Landier, A., 2001, "The Perverse Effect of Partial Labor Market Reform: Fixed Duration Contracts in France," NBER Working Paper 8219.

Blinder, Alan S, 2009, "How Many U.S. Jobs Might Be Offshorable.” World Economics 10 (2), pp. 41-78.

Byeon, Y., Choi, K., Choi, H., and Kim, J., 2017, “Korea's Paradigm Shift for Sustainable and Inclusive Growth: A Proposal", IMF Working Paper, WP/17/260. 
Cabrales, A., J. Dolado, and R. Mora, 2014, "Dual Labour Markets and (Lack of) On-the-Job Training: PIAAX Evidence from Spain and Other EU Countries," IZA Discussion Paper No. 8649.

Card, David, J. Kluve, and A. Weber, 2010, “Active Labour Market Policy Evaluations: A Meta-Analysis," The Economic Journal, 120, pp.452-477.

Card, David, Kluve, J., and Weber, A., 2015, "What Works? A Meta Analysis of Recent Active Labor Market Program Evaluations," Institute for the Study of Labor (IZA). Discussion Paper No. 9236.

Cho, J., and Keum, J., 2009, "Dualism in Job Stability of the Korean Labour Market: The Impact of the 1997 Financial Crisis," Pacific Economic Review, 14:1, pp. 155-175.

Cooke, F., and Brown, R., 2015, “The Regulation of Non-Standard Forms of Employment in China, Japan and The Republic of Korea," ILO Conditions of Work and Employment Series No.64.

Crépon, B., and van den Berg, G., 2016, "Active Labor Market Policies", Annual Review of Economics, Volume 8, Number 1, pp.521-546.

Dao, M., Furceri, D., Hwang, J., Kim, M., and Kim, T., 2014,“ Strategies for Reforming Korea's Labor Market to Foster Growth,” IMF Working Paper, WP/14/137.

Dolado, J., Lale, E., and Siassi, N., 2017, "From Dual to Unified Employment Protection: Transition and Steady State", Working Paper, April 2017.

Dolado, J., Ortigueira, S., and Stucchi, R., 2016, "Does Dual Employment Protection Affect TFP? Evidence from Spanish Manufacturing Firms," SERIEs, Volume 7, Issue 4, pp. 421-459.

Eichengreen, Barry and others, 2015, “The Korean economy. From a Miraculous Past to a Sustainable Future," Harvard University Asia Center.

Grubb, D., Lee, J., and Tergeist,P., 2007, "Addressing Labour Market Duality in Korea," OECD Social , Employment and Migration Working Papers No.61.

Ha, B., and Lee, S., 2013, "Dual dimensions of non-regular work and SMEs in the Republic of Korea", ILO Employment Working Paper No.148.

IFR, 2017, "Executive Summary World Robotics 2017 Industrial Robots".

IMF, 2016a, “Republic of Korea, Article IV Staff Report,” IMF Country Report No. 16/278. 
IMF, 2016b, "Time for a Supply-Side Boost? Macroeconomic Effects of Labor and Product Market Reforms in Advanced Economies." World Economic Outlook, Chapter 3, Washington, DC, April.

IMF, 2018a, "Republic of Korea, Article IV Staff Report,” IMF Country Report No. 18/40.

IMF, 2018b, “Republic of Korea, Selected Issues,” IMF Country Report No. 18/41.

Kettemann, A., Kramarz, F., and Zweimüller, 2017, “Job Mobility and Creative Destruction: Flexicurity in the Land of Schumpeter," Working Paper.

Kim, Y., 2011, "The Size and Conditions of Non-regular Employment," Labor \& Society, Vol. 162.

Kim, H., 2014, “Intergenerational Mobility and the Role of Education in Korea," Korea Development Institute.

Kim, H., 2015a, "Directions for Improving Korea's Employment Legislation to Reduce the Duality of the Labor Market," e-Labor News No. 154.

Kim, Y., 2015b, “The Youth Labor Market in Korea: Current Situation and Employment Policy," Korea Labor Institute.

Kim, H., 2016, “Three Dualization Processes in Korea: The Labor Market, Welfare Policy and Political Representation," Development and Society, Volume 45, Number 2.

Kim, S., and Lee, J., 2014, “Accounting for Ins and Outs of Unemployment in Korea," Korea and the World Economy, Vol.15, No.1, pp.17-44.

Kim, H. and Skott, P., 2016, “ Labor Market Reforms, Temporary Workers and Wage Inequality,” Metroeconomics, 67:2, pp.313-333.

Lee, I. , 2011, "Wage Differential Between Standard and Non-standard Workers: Evidence from an Establishment-Worker Method Matched Data," Korean Journal of Labor Economics, 34(3), pp.119-139.

Lee, H., and Lee, J., 2015, “The Impact of Offshoring on Temporary Workers: Evidence on Wages from South Korea,” Rev. World Econ. 151, pp. 555-587.

Lindbeck and Snower, 2002, “The Insider-Outsider Theory: A Survey," IZA Discussion Paper, No.534.

McGowan, M., and Andrews, D., 2015, "Skill Mismatch and Public Policy in OECD Countries," OECD Working Paper, ECO/WKP(2015)28. 
Ministry of Foreign Affairs of Denmark, http://denmark.dk/en/society/welfare/flexicurity, accessed October, 2017.

Ministry of Strategy and Finance (MoSF), 2017, "Paradigm Shifted For Sustainable Growth", Press Release.

Reijnders, L., and de Vries, G., 2017, “Job Polarization in Advanced and Emerging Countries: The Role of Task Relocation and Technological Change within Global Supply Chains." GGDC Research Memorandum 167.

Saint-Paul, G., 1996, “Dual Labor Markets. A Macroeconomic Perspective,” The MIT Press.

Saint-Paul, G., 2002, "Employment Protection, International Specialization, and Innovation", European Economic Review, 46(2), pp.375-395.

Shin, S., 2009, "An Empirical Analysis of the Wage Differentials between Regular and Iirregular Workers in Korean Labor Markets," Korean Society, 10(2), 93-123.

OECD, 2013, "Strengthening Social Cohesion in Korea," OECD Publishing, Paris. http://dx.doi.org/10.1787/9789264188945-en

OECD, 2015, "Pensions at a Glance 2015: OECD and G20 Indicators," OECD Publishing, Paris. http://dx.doi.org/10.1787/pension_glance-2015-en

OECD, 2016, “OECD Economic Surveys: Korea 2016,” OECD Publishing, Paris. http://dx.doi.org/10.1787/eco surveys-kor-2016-en

OECD, 2017a, "Labour Force Statistics in OECD Countries: Sources, Coverage and Definitions," last update June 2017.

OECD, 2017b, "Labour Market Reforms in Portugal 2011-2015. A Preliminary Assessment." OECD Publishing, Paris. http://dx.doi.org/10.1787/9789264269576-en

Wilthagen, T., Frank, T., and van Lieshout, H., 2003, “Towards 'Flexicurity’?: Balancing Flexibility and Security in EU Member States," paper presented at the 13th World Congress of the International Industrial Relations Association (IIRA), Berlin.

Zhou, J., 2007, "Danish for All? Balancing Flexibility with Security: The Flexicurity Model," IMF Working Paper, WP/07/36. 


\section{Appendix}

Appendix A1. Official Employment Classifications by the Korean Statistics Office

\begin{tabular}{|c|l|l|}
\hline \multicolumn{2}{|c|}{ Classification by Employment Status } \\
\hline \multirow{2}{*}{$\begin{array}{c}\text { Won-salaried Workers } \\
\text { Wage and Salary } \\
\text { Workers }\end{array}$} & Employer, own account workers, unpaid family workers \\
\cline { 2 - 3 } & Regular Employees & Contract length of at least one year. \\
\cline { 2 - 3 } & Temporary Employees & $\begin{array}{l}\text { Contract length is more than a month to less than a year or } \\
\text { no employment contracts but employed for more than a } \\
\text { month to less than a year to complete a project. }\end{array}$ \\
\cline { 2 - 3 } & Daily Workers & $\begin{array}{l}\text { Contract for less than a month or employed on a daily basis } \\
\text { and receive daily wages for their labor and services } \\
\text { rendered. }\end{array}$ \\
\hline
\end{tabular}

Classification by Employment Type

\begin{tabular}{|l|l|l|}
\hline Regular Workers & \multicolumn{2}{|l|}{ Defined as not being non-regular. } \\
\hline $\begin{array}{l}\text { Non-Regular Workers } \\
\text { (sub-groups are }\end{array}$ & $\begin{array}{l}\text { Non-permanent Workers } \\
\text { (Contingent) }\end{array}$ & Contracts with prescribed contract period. \\
\cline { 2 - 3 } $\begin{array}{l}\text { overlapping, e.g. } \\
\text { workers can be part- } \\
\text { time and non- } \\
\text { permanent) }\end{array}$ & $\begin{array}{l}\text { Employment that carries fewer hours than a full-time job or } \\
\text { pays wages paid by the hour. }\end{array}$ \\
\cline { 2 - 3 } & Non-typical Workers & $\begin{array}{l}\text { Includes temporary agency workers, contract form workers, } \\
\text { independent contractors, tele-workers, on-call workers. }\end{array}$ \\
\hline
\end{tabular}

\section{Appendix A2. Description of Korean Labor and Income Panel Survey (KLIPS)}

KLIPS is a representative longitudinal survey of the labor market and income activities of about 5000 household and 13000 individuals residing in urban areas. It has been conducted since 1998 by the Korea Labor Institute with the support of the Ministry of Employment and Labor. The sample is an equal probability sample of households from seven metropolitan cities and urban areas in eight provinces. In Wave 12 (2009), a sample of 1,415 households was added to improve the national representativeness. However, KLIPS is not fully representative as it only includes urban areas. The results using this data should thus be interpreted with this caveat in mind. The latest available wave available for analysis is 2014 (wave 17). For more information see https://www.kli.re.kr/klips_eng/ and the user's guide that can be found there. 
Appendix A3. Description of Data and Methodology for Figure 19 and 20

The data used for this analysis is the Survey on Labor Conditions by Employment Type conducted by the Ministry of Employment of Labor (http://www.moel.go.kr/english/pas/pasMOEL.jsp). The dataset provides information on employment, monthly wages, and total hours worked by occupation from 1993 to 2016. These occupations are mapped to three wage levels (high, medium, low) following the methodology in Reijnders and de Vries (2017) (see Table A3.1.). While the occupation groupings change somewhat for different periods, they are classified so as to ensure continuity as much as possible.

\begin{tabular}{|c|c|c|c|}
\hline Wage Level & 2009 to 2016 & 2000 to 2008 & 1993 to 1999 \\
\hline \multirow{2}{*}{ High } & Managers & Senior officials and managers & Senior officials and managers \\
\hline & Professionals and related workers & Professionals & Professionals \\
\hline \multirow{4}{*}{ Middle } & $\begin{array}{l}\text { Equipment, machine operating and assembling } \\
\text { workers }\end{array}$ & Plant, machine, operators and assemblers & Plant and machine operators and assemblers \\
\hline & Craft and related trades workers & Craft and related trades workers & Craft and related trades workers \\
\hline & Clerks & Clerks & Clerks \\
\hline & Skilled agricultural, forestry and fishery workers & $\begin{array}{l}\text { Skilled agricultural, forestry, fishery and related } \\
\text { workers }\end{array}$ & Skilled agricultural amd fishery workers \\
\hline \multirow{3}{*}{ Low } & Elementary workers & Elementary occupations & Elementary occupations \\
\hline & Sales workers & Sales workers & $\begin{array}{l}\text { Service workers and shop and market sales } \\
\text { workers }\end{array}$ \\
\hline & Service workers & Services workers & \\
\hline
\end{tabular}

